\title{
Hydrogen Peroxide used as a Solar Fuel in One-Compartment Fuel Cells
}

\section{Shunichi Fukuzumi and Yusuke Yamada}

\begin{tabular}{|c|l|}
\hline Citation & ChemElectroChem,3(12): 1978-1989 \\
\hline Issue Date & $2016-12-13$ \\
\hline Type & Journal Article \\
\hline Textversion & author \\
\hline Rights & $\begin{array}{l}\text { This is the peer reviewed version of the following article: FUKUZUMI, S., \& } \\
\text { YAMADA, Y. (2016). Hydrogen Peroxide used as a Solar Fuel in One-Compartment } \\
\text { form at https://doi.org/10.1002/celc.201600317 . This article may be used for } \\
\text { non-commercial purposes in accordance with Wiley Terms and Conditions for } \\
\text { Self-Archiving. }\end{array}$ \\
\hline DOI & \begin{tabular}{l} 
10.1002/celc.201600317 \\
\hline
\end{tabular}
\end{tabular}

\author{
Self-Archiving by Author(s) \\ Placed on: Osaka City University Repository
}




\section{Hydrogen Peroxide used as a Solar Fuel in One- Compartment Fuel Cells}

Shunichi Fukuzumi*[a,b] and Yusuke Yamada*c]

Dedicated to Prof. Cristian Amatore on the occasion of his 65th birthday

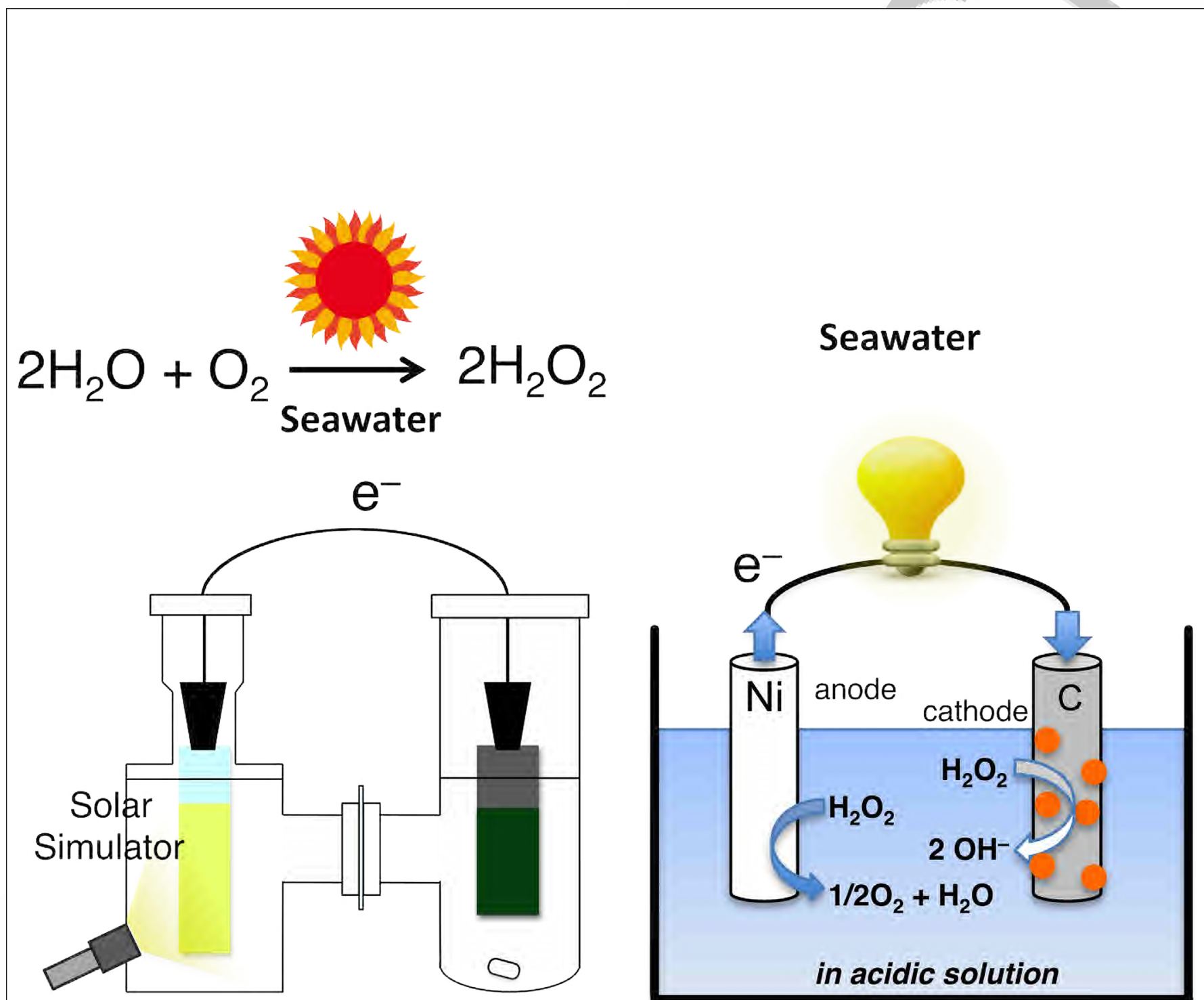


Clean and highly efficient production of solar fuels as well as effective methods to store solar fuels have long been sought to solve global energy and environmental issues. Among solar fuels such as gaseous hydrogen and carbon monoxide, aqueous hydrogen peroxide $\left(\mathrm{H}_{2} \mathrm{O}_{2}\right)$ is an ideal chemical for energy storage, because endothermic $\mathrm{H}_{2} \mathrm{O}_{2}$ decomposition produces only water and oxygen. In addition, $\mathrm{H}_{2} \mathrm{O}_{2}$ can be transported in plastic containers with a high energy density. $\mathrm{H}_{2} \mathrm{O}_{2}$ can be converted into electricity by using $\mathrm{H}_{2} \mathrm{O}_{2}$ fuel cells without a mem- brane and composed of an anode and a cathode, and they can selectively catalyze $\mathrm{H}_{2} \mathrm{O}_{2}$ oxidation or reduction. The onecompartment structure without a membrane is more promising to develop low-costing fuel cells than a two-compartment structure with expensive membranes. This article provides a focused review of recent developments and future perspectives of $\mathrm{H}_{2} \mathrm{O}_{2}$ fuel cells without membranes, combined with $\mathrm{H}_{2} \mathrm{O}_{2}$ production from seawater and dioxygen in the air by utilizing solar energy.

\section{Introduction}

Global warming caused by the production of greenhouse gases from the combustion of fossil fuels has prompted the development of alternative, renewable energy sources by using solar energy and effective storage. ${ }^{[1-4]}$ Hydrogen can produce electricity by using hydrogen fuel cells, and electricity can produce hydrogen by electrolysis; hydrogen is renewable and harmless to the environment, because hydrogen produces energy by oxidation with dioxygen to yield only water. ${ }^{[5-8]}$ However, high-pressure tanks (35.0-70.0 MPa converted into SI unit $\square$ ) are necessary to store gaseous hydrogen, whereas cryogenic temperatures are demanded to store hydrogen in liquid form because the boiling point of hydrogen is as low as $-252.8^{\circ} \mathrm{C}$ at atmospheric pressure. ${ }^{[5-8]}$ Current industrial production processes of hydrogen are expensive and energy consuming, and they often involve the use of fossil fuels. In addition, an effective infrastructure for supplying hydrogen has yet to be established. $\mathbf{\square}$ paragraph ok?

In contrast to hydrogen, hydrogen peroxide $\left(\mathrm{H}_{2} \mathrm{O}_{2}\right)$, a liquid with high energy density, is a promising energy carrier for portable devices in the next generation, because safety of $\mathrm{H}_{2} \mathrm{O}_{2}$ is guaranteed not only in aqueous solution but also in solid form through the formation of adducts with urea or carbonate, for which the $\mathrm{H}_{2} \mathrm{O}_{2}$ concentration can reach higher than about $30 \mathrm{wt} \% .^{[9-15]}$ Concentrated hydrogen peroxide is a compound regulated by the Environmental Protection Agency (EPA), because it is hazardous at $>52 \mathrm{wt} \%$, which may be an upper concentration limit for practical applications. ${ }^{[9]}$ Nevertheless, this limitation should not prevent its use as a fuel, because concentrated $\mathrm{H}_{2} \mathrm{O}_{2}$ is a stable liquid as long as

[a] Prof. Dr. S. Fukuzumi

Department of Chemistry and Nano Science

Ewha Womans University

Seoul 120-750 (Korea)

[b] Prof. Dr. S. Fukuzumi

Faculty of Science and Engineering, Meijo University

ALCA and SENTAN (Japan) Science and Technology Agency (JST)

Nagoya, Aichi 468-8502 (Japan)

E-mail:fukuzumi@chem.eng.osaka-u.ac.jp

[c] Prof. Dr. Y. Yamada

Department of Applied Chemistry and Bioengineering

Graduate, School of Engineering, Osaka City University

3-3-138 Sugimoto, Sumiyoshi, Osaka 558-8585 (Japan)

E-mail:ymd@a-chem.eng.osaka-cu.ac.jp

This is an invited contribution for the Christian Amatore Festschrift it is not exposed to metals that catalyze its decomposition into water and oxygen or organic compounds that pose a combus tion threat. $\mathrm{H}_{2} \mathrm{O}_{2}$ is fairly nontoxic but corrosive even at high concentrations $(\approx 20 \mathrm{M})$. Thus, $\mathrm{H}_{2} \mathrm{O}_{2}$ in a plastic container can provide high portability with a high energy density per volume. ${ }^{[9-15]}$ Because the disproportionation of two $\mathrm{H}_{2} \mathrm{O}_{2}$ molecules to $\mathrm{H}_{2} \mathrm{O}$ and $\mathrm{O}_{2}$ releases a large amount of energy (Figure 1), ${ }^{[15-18]} \mathrm{H}_{2} \mathrm{O}_{2}$ has been used as an effective fuel and oxidant in rocket propulsion ${ }^{[19-24]}$ and micromotors. ${ }^{[25-30]}$ In industry, $\mathrm{H}_{2} \mathrm{O}_{2}$ is produced by the anthraquinone catalytic process, in which $\mathrm{O}_{2}$ is reduced by $\mathrm{H}_{2}{ }^{[31,32]}$

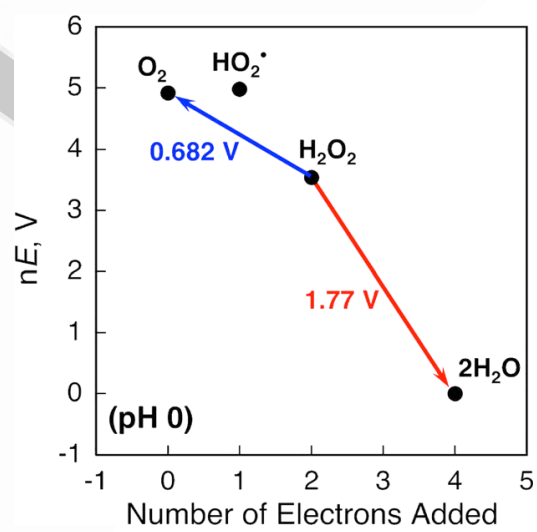

Figure 1. Frost diagrams for $\mathrm{O}_{2}$ activation.

To utilize $\mathrm{H}_{2} \mathrm{O}_{2}$ as a solar fuel, $\mathrm{H}_{2} \mathrm{O}_{2}$ should be produced by oxidation of $\mathrm{H}_{2} \mathrm{O}$ with $\mathrm{O}_{2}$ by using solar energy and used as a fuel for $\mathrm{H}_{2} \mathrm{O}_{2}$ fuel cells. ${ }^{[12-15]} \mathrm{H}_{2} \mathrm{O}_{2}$ is indeed produced by using solar energy in photosynthesis, for which $5-10 \%$ of the total photosynthetic electron flow in $\mathrm{C} 3$ plants is consumed to reduce $\mathrm{O}_{2}$ to $\mathrm{H}_{2} \mathrm{O}_{2}$ under normal functional conditions, and this can increase to more than $30 \%$ under stress conditions. ${ }^{[15,33-35]}$

From a thermodynamic point of view, the overall efficiency of the $\mathrm{H}_{2} \mathrm{O}_{2}-\mathrm{O}_{2}$ system potentially exceeds that of the $\mathrm{H}_{2}-\mathrm{H}_{2} \mathrm{O}$ system. For production of $\mathrm{H}_{2} \mathrm{O}_{2}$ and $\mathrm{H}_{2}$, the Gibbs energy change for the production of $\mathrm{H}_{2} \mathrm{O}_{2}$ by $\mathrm{O}_{2}$ reduction with water is $117 \mathrm{~kJ} \mathrm{~mol}^{-1},{ }^{[36]}$ which is almost half that for $\mathrm{H}_{2} \mathrm{O}$ reduction to $\mathrm{H}_{2}\left(237 \mathrm{~kJ} \mathrm{~mol}^{-1}\right) .^{[36]}$ Also, the thermodynamic efficiency of the fuel cell is given by the ratio of the Gibbs energy change $\left(\Delta G^{\circ}\right)$ to the enthalpy change $\left(\Delta H^{\circ}\right)$ in the overall cell reaction. The $\Delta G^{\circ}$ and $\Delta H^{\circ}$ values measure the electrical work and the internal energy of the fuel, respectively. Therefore, the efficiency of 
the ideal $\mathrm{H}_{2}$ fuel cell is $83 \%\left[=\Delta G^{\circ} / \Delta H^{\circ}\left(-237 \mathrm{~kJ} \mathrm{~mol}^{-1}\right) /\right.$ $\left.\left(-286 \mathrm{~kJ} \mathrm{~mol}^{-1}\right)\right] .^{[36]}$ On the other hand, the efficiency of the ideal $\mathrm{H}_{2} \mathrm{O}_{2}$ fuel cell is higher than $100 \%\left(-\Delta G^{\circ}>-\Delta H^{\circ}\right) .^{[36]}$

At present, the power density of conventional $\mathrm{H}_{2}$ fuel cells exceeds more than $1 \mathrm{~W} \mathrm{~cm}^{-2[37]}$ on the other hand, and that of $\mathrm{H}_{2} \mathrm{O}_{2}$ fuel cells remains lower than $10 \mathrm{~mW} \mathrm{~cm}^{-2}$ on the other hand (Tables 1 and 2). ${ }^{[38-53]}$ Thus, $\mathrm{H}_{2} \mathrm{O}_{2}$ fuel cells are not yet suitable for large-scale electric devices such as automobiles, but they are used for personal-based small electric items such as cell phones. Although the gravimetric energy density of $\mathrm{H}_{2} \mathrm{O}_{2}$ is as low as $0.85 \mathrm{kWh} \mathrm{kg}^{-1}$, which is about 40 times lower than that $\left(33 \mathrm{kWh} \mathrm{kg}^{-1}\right)$ of $\mathrm{H}_{2}$, the volumetric energy density of pure $\mathrm{H}_{2} \mathrm{O}_{2}\left(1230 \mathrm{WhL}^{-1}\right)$ is more than 400 times larger than that of $\mathrm{H}_{2}\left(2.9 \mathrm{WL}^{-1}\right)$ under standard ambient temperature and pressure. Thus, the volumetric energy density of an aqueous 30 wt $\% \mathrm{H}_{2} \mathrm{O}_{2}$ solution is equal to that of $\mathrm{H}_{2}$ compressed under a high pressure of $10 \mathrm{MPa}$. Whereas a gas tank with high strength is necessary for $\mathrm{H}_{2}$ transportation, a lightweight plastic bottle is sufficient to store and transport $\mathrm{H}_{2} \mathrm{O}_{2}$. Thus, at present, $\mathrm{H}_{2} \mathrm{O}_{2}$ can be regarded as a solar fuel for small personal-based devices.

This minireview focuses on recent developments of onecompartment $\mathrm{H}_{2} \mathrm{O}_{2}$ fuel cells, which are combined with the production of $\mathrm{H}_{2} \mathrm{O}_{2}$ from $\mathrm{H}_{2} \mathrm{O}$ and $\mathrm{O}_{2}$ by using solar energy. $\mathrm{H}_{2} \mathrm{O}_{2}$ fuel cells can generate a theoretical output voltage of

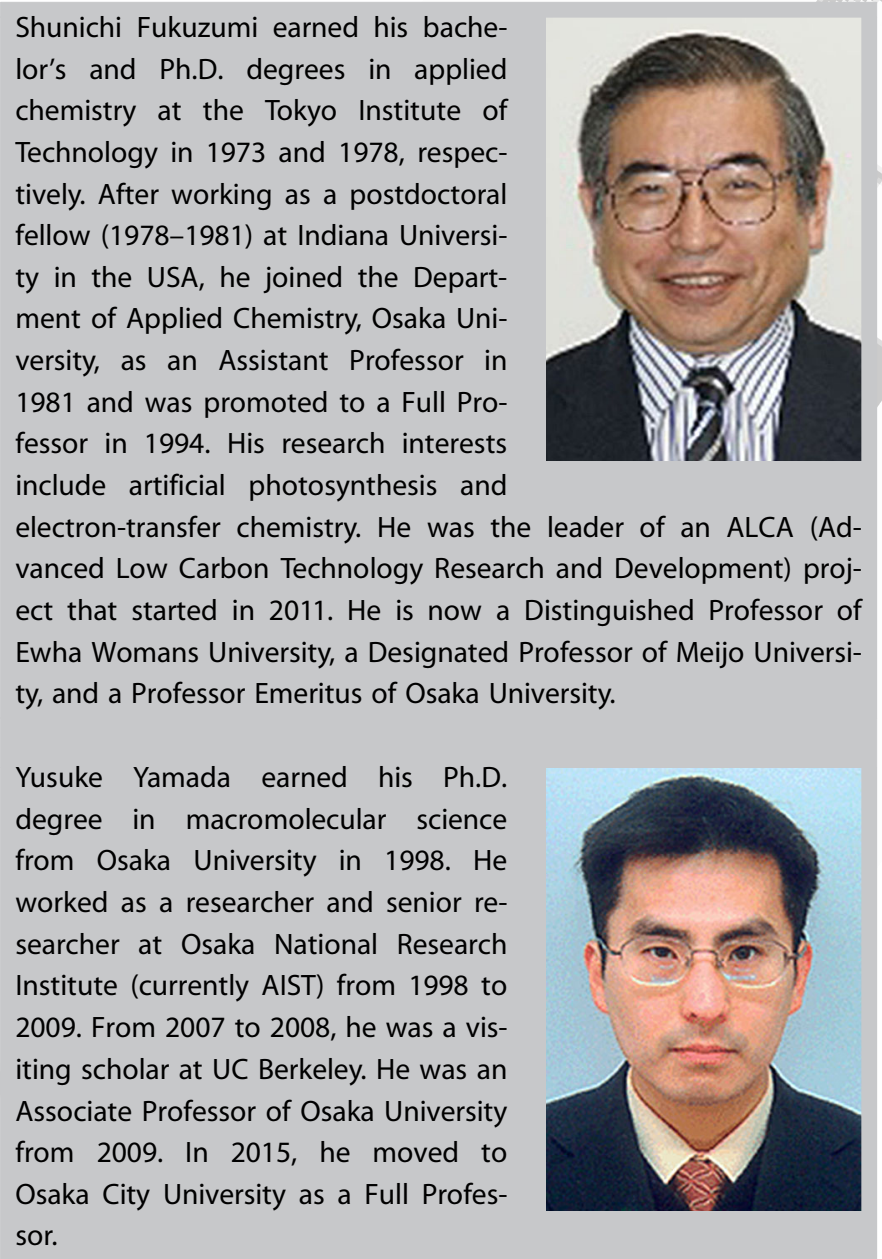

Shunichi Fukuzumi earned his bachelor's and Ph.D. degrees in applied chemistry at the Tokyo Institute of Technology in 1973 and 1978, respectively. After working as a postdoctoral fellow (1978-1981) at Indiana University in the USA, he joined the Department of Applied Chemistry, Osaka University, as an Assistant Professor in 1981 and was promoted to a Full Professor in 1994. His research interests include artificial photosynthesis and electron-transfer chemistry. He was the leader of an ALCA (Advanced Low Carbon Technology Research and Development) project that started in 2011. He is now a Distinguished Professor o Ewha Womans University, a Designated Professor of Meijo UniversiYusuke Yamada earned his Ph.D. degree in macromolecular science from Osaka University in 1998. He worked as a researcher and senior researcher at Osaka National Research Institute (currently AIST) from 1998 to 2009. From 2007 to 2008, he was a visiting scholar at UC Berkeley. He was an Associate Professor of Osaka University sor.
$1.09 \mathrm{~V}$ by utilizing $\mathrm{H}_{2} \mathrm{O}_{2}$ as both a fuel at the cathode and an oxidant at the anode with the emission of $\mathrm{H}_{2} \mathrm{O}$ and $\mathrm{O}_{2}$ after power generation (Figure 1). In particular, $\mathrm{H}_{2} \mathrm{O}_{2}$ is produced from seawater, which is the most earth-abundant resource, and $\mathrm{O}_{2}$ in the air by using solar energy, and the $\mathrm{H}_{2} \mathrm{O}_{2}$ thus produced is directly consumed as a fuel in seawater for $\mathrm{H}_{2} \mathrm{O}_{2}$ fuel cells to generate electrical power on demand.

\section{Development of One-Compartment Hydro- gen Peroxide Fuel Cells without a Membrane}

Proton-exchange membrane (PEM) fuel cells normally require oxygen as the oxidant, and the reductant is separated by the membrane. Aqueous $\mathrm{H}_{2} \mathrm{O}_{2}$ has been utilized as an alternative oxidant in various types of fuel cells by using borohydride, ${ }^{[54-58]}$ metals, ${ }^{[59-63]}$ methanol, ${ }^{[64-66]}$ ethanol, ${ }^{[67,68]}$ hydrazine, ${ }^{[69]} \mathrm{H}_{2} \mathrm{~S}^{[70,71]}$ and biofuels ${ }^{[54,55]}$ as reductants. The fabrication of one-compartment fuel cells without expensive membranes by employing only one chemical as both the fuel and the oxidant seems to be a valuable approach to develop low-costing fuel cells. $\mathrm{H}_{2} \mathrm{O}_{2}$ can be used not only as an oxidant but also as a reductant, and thereby, one-compartment $\mathrm{H}_{2} \mathrm{O}_{2}$ fuel cells have recently been developed. ${ }^{[38-45]}$ One-compartment $\mathrm{H}_{2} \mathrm{O}_{2}$ fuel cells have various advantages over other fuel cells including hydrogen fuel cells. First of all, $\mathrm{H}_{2} \mathrm{O}_{2}$ is liquid and freely miscible with water and is thereby easy to store and carry in an appropriate container in comparison with hydrogen, which needs a highpressure tank. Indeed, an aqueous solution of $\mathrm{H}_{2} \mathrm{O}_{2}$ supplied by a chemical company is kept in a plastic container. Most importantly, no expensive membranes are required for one-compartment $\mathrm{H}_{2} \mathrm{O}_{2}$ fuel cells, because $\mathrm{H}_{2} \mathrm{O}_{2}$ can act as both the oxidant and the reductant depending on the catalytic activities of the electrodes using the same $\mathrm{H}_{2} \mathrm{O}_{2}$ solution. $\mathrm{H}_{2} \mathrm{O}_{2}$ provides more energy than $\mathrm{O}_{2}$ for the fuel cell and increases the cell performance, because $\mathrm{H}_{2} \mathrm{O}_{2}$ has a higher standard reduction potential $\left(E^{\circ}=1.77 \mathrm{~V}\right.$ vs. $\left.\mathrm{NHE}\right)$ than $\mathrm{O}_{2}\left(E^{\circ}=1.23\right.$ vs. $\left.\mathrm{NHE}\right) .^{[15]}$ Furthermore, $\mathrm{H}_{2} \mathrm{O}_{2}$ does not cause the environmental problems associated with most other chemical reductants and oxidants.

The anodic and cathodic reactions at the electrodes of $\mathrm{H}_{2} \mathrm{O}_{2}$ fuel cells are given by Equations (1) and (2), respectively. ${ }^{[13-15]}$ The overall reaction [Eq. (3)] indicates that $\mathrm{H}_{2} \mathrm{O}_{2}$ fuel cells emit only $\mathrm{O}_{2}$ and $\mathrm{H}_{2} \mathrm{O}$ after electrical power generation. The theoretically expected output potential of the $\mathrm{H}_{2} \mathrm{O}_{2}$ fuel cell is $1.09 \mathrm{~V}$, which is slightly lower but similar to those of a hydrogen fuel cell and a direct methanol fuel cell (1.23 and $1.21 \mathrm{~V}$, respectively). ${ }^{[13-15]}$

Anode : $\mathrm{H}_{2} \mathrm{O}_{2} \rightarrow \mathrm{O}_{2}+2 \mathrm{H}^{+}+2 \mathrm{e}^{-} \quad 0.68 \mathrm{Vvs.} \mathrm{NHE}$

Cathode: $\mathrm{H}_{2} \mathrm{O}_{2}+2 \mathrm{H}^{+}+2 \mathrm{e}^{-} \rightarrow 2 \mathrm{H}_{2} \mathrm{O} \quad 1.77 \mathrm{Vvs}$. NHE

Total : $2 \mathrm{H}_{2} \mathrm{O}_{2} \rightarrow \mathrm{O}_{2}+2 \mathrm{H}_{2} \mathrm{O} \quad 1.09 \mathrm{~V}$

The first one-compartment $\mathrm{H}_{2} \mathrm{O}_{2}$ fuel cell employed an $\mathrm{Au}$ plate and an $\mathrm{Ag}$ plate as the anode and cathode, respectively, in an aqueous solution containing $1 \mathrm{M} \mathrm{NaOH}$ and $300 \mathrm{~mm} \mathrm{H}_{2} \mathrm{O}_{2}$ (Figure 2), because these metal plates act as selective oxidation 


\begin{tabular}{|c|c|c|c|c|c|}
\hline Anode & Cathode & $\mathrm{pH}$ & $\mathrm{OCP}[\mathrm{V}]$ & $\mathrm{MPD}\left[\mathrm{mW} \mathrm{cm}^{-2}\right]$ & Ref. \\
\hline $\mathrm{Au}$ & $\mathrm{Ag}$ & 14 & 0.095 & 0.07 & [38] \\
\hline $\mathrm{Au}$ & $\mathrm{Ag}-\mathrm{Pb}$ & 14 & 0.15 & 0.07 & [39] \\
\hline $\mathrm{Ni}$ & $\mathrm{Fe}(\mathrm{II}(\mathrm{Pc}) \mathrm{Cl}$ & 3 & 0.5 & 0.01 & [40] \\
\hline $\mathrm{Ni}$ & Prussian blue & 1 & 0.60 & 1.55 & [41] \\
\hline $\mathrm{Ag}$ & Prussian blue & 1 & 0.52 & 0.7 & [41] \\
\hline $\mathrm{Ni}$ & $\mathrm{Fe}^{\mathrm{e}}\left[\mathrm{Co} \mathrm{o}^{\prime \prime \prime}(\mathrm{CN})_{6}\right]$ & 1 & 0.80 & 1.0 & [42] \\
\hline $\mathrm{Ni}$ & $\mathrm{Fe}^{\mathrm{e}}\left[\mathrm{Co}^{\prime \prime \prime}(\mathrm{CN})_{6}\right]$ (heat treated) & $1\left(\mathrm{Sc}^{3+}\right)$ & 0.81 & 9.9 & [43] \\
\hline \multirow[t]{2}{*}{$\mathrm{Ni}$} & $\mathrm{Fe}^{\prime \prime}\left[\mathrm{Pt}(\mathrm{CN})_{4}\right](\mathrm{pyz})$ & 1 & 0.7 & 4 & [44] \\
\hline & $\mathrm{Fe}^{\mathrm{el}}\left[\mathrm{Pd}(\mathrm{CN})_{4}\right](\mathrm{pyz})^{[\mathrm{aj}]}$ & 1 & 0.78 & 4 & [44] \\
\hline $\mathrm{Ni}$ & $\mathrm{Fe}^{\prime \prime \prime}\left(9\right.$-hydroxyphenalenone) ${ }_{3}$ & 1 & 0.74 & 1.43 & [45] \\
\hline
\end{tabular}

[a] $\mathbf{\square}$ pyz = please define $\mathbf{\square}$

\begin{tabular}{|c|c|c|c|c|c|c|}
\hline Cathode & Catholite & Anode & Anolite & OCP $[\mathrm{V}]$ & MPD $\left[\mathrm{mW} \mathrm{cm}^{-2}\right]$ & Ref. \\
\hline \multirow[t]{2}{*}{$\mathrm{Pt}$} & \multirow[t]{2}{*}{$1.5 \mathrm{M} \mathrm{H}_{2} \mathrm{SO}_{4}$} & \multirow[t]{2}{*}{$\mathrm{Ni}$} & \multirow[t]{2}{*}{$6 \mathrm{~m} \mathrm{KOH}$} & 0.90 & 3.9 & [46] \\
\hline & & & & 0.90 & $58.4\left(60^{\circ} \mathrm{C}\right)$ & [47] \\
\hline $\mathrm{Au} @ \mathrm{Pd}$ & $2 \mathrm{M} \mathrm{H}_{2} \mathrm{SO}_{4}$ & $\mathrm{Au} @ \mathrm{Pd}$ & $4 \mathrm{~m} \mathrm{KOH}$ & 0.90 & 20.7 & [48] \\
\hline $\mathrm{Pt}$ & $1.5 \mathrm{M} \mathrm{H}_{2} \mathrm{SO}_{4}$ & $\mathrm{PbSO}_{4}$ & $3 \mathrm{~m} \mathrm{KOH}$ & $\approx 1$ & 10 & [49] \\
\hline $\mathrm{Au}$ & $2 \mathrm{M} \mathrm{H}_{2} \mathrm{SO}_{4}$ & $\mathrm{Au}$ & $4 \mathrm{~m} \mathrm{KOH}$ & 0.8 & 14 & [50] \\
\hline \multirow[t]{2}{*}{$\mathrm{Pd}$} & \multirow{2}{*}{$2 \mathrm{M} \mathrm{H}_{2} \mathrm{SO}_{4}$} & \multirow[t]{2}{*}{$\mathrm{Ni}$} & \multirow{2}{*}{$4 \mathrm{~m} \mathrm{KOH}$} & \multirow[t]{2}{*}{0.9} & $21.6\left(20^{\circ} \mathrm{C}\right)$ & [51] \\
\hline & & & & & $53.8\left(50^{\circ} \mathrm{C}\right)$ & [51] \\
\hline $\mathrm{Pd}$ & $2 \mathrm{M} \mathrm{H}_{2} \mathrm{SO}_{4}$ & $\mathrm{Ni}$ & $4 \mathrm{M} \mathrm{KOH}$ & 0.9 & $48.7\left(20^{\circ} \mathrm{C}\right)$ & [52] \\
\hline
\end{tabular}

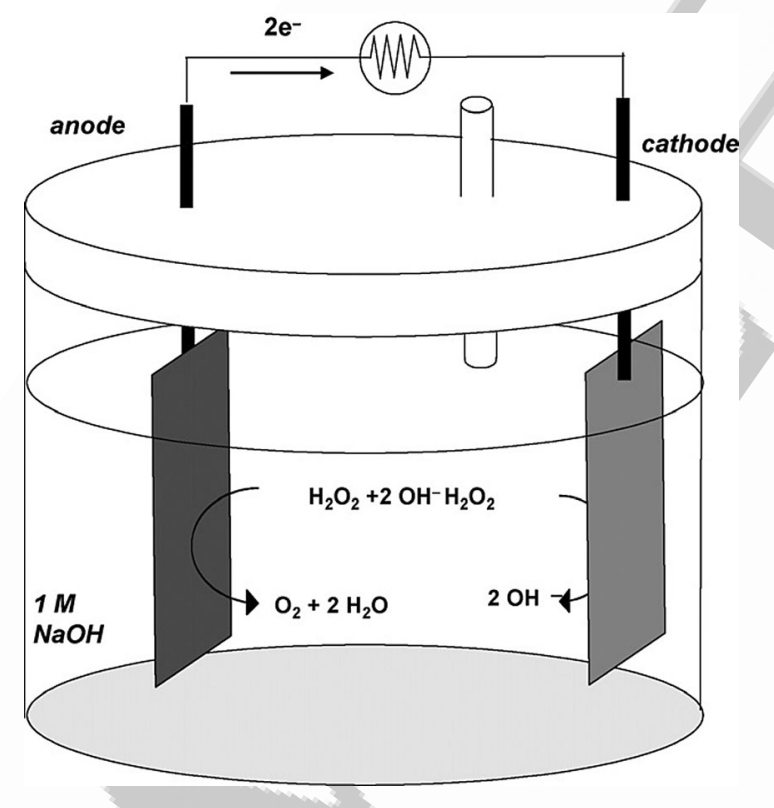

Figure 2. One-compartment $\mathrm{H}_{2} \mathrm{O}_{2}$ fuel cell under basic conditions ( $\left.\mathrm{pH} 14\right)^{[38]}$

and reduction electrocatalysts toward $\mathrm{H}_{2} \mathrm{O}_{2}$, respectively. ${ }^{[38]}$ However, the open-circuit potential (OCP) was as low as $0.095 \mathrm{~V}$ (Figure 3), which is much lower than the theoretically expected output voltage of $1.09 \mathrm{~V}^{[38]}$ The low OCP value results from a large overpotential at the $\mathrm{Ag}$ cathode. ${ }^{[38]}$

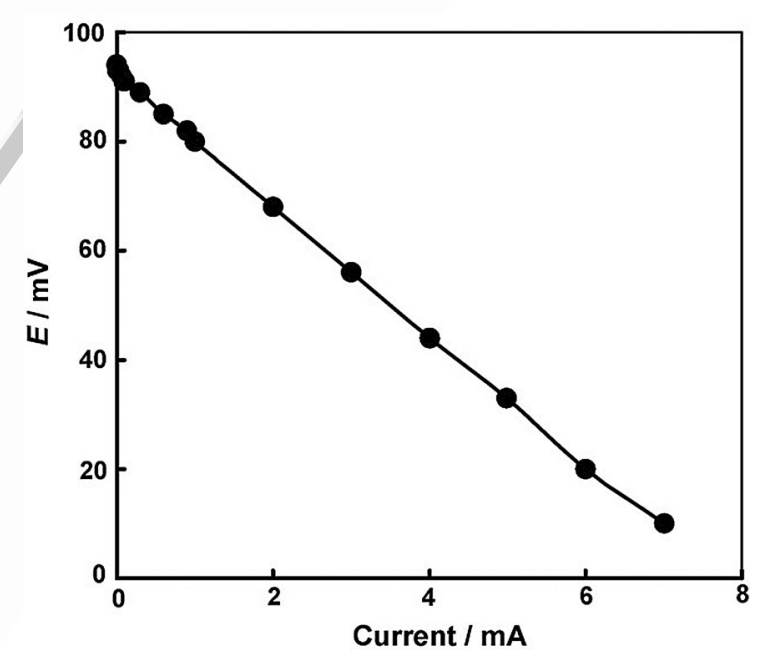

Figure 3. $I-V$ curve of a one-compartment $\mathrm{H}_{2} \mathrm{O}_{2}$ fuel cell with a Au anode and $\mathrm{a} \mathrm{Ag}$ cathode. Performance tests were conducted in aqueous solution containing $1 \mathrm{M} \mathrm{NaOH}$ and $300 \mathrm{mM} \mathrm{H}_{2} \mathrm{O}_{2}$. The electrode surface areas were fixed at $2.4 \mathrm{~cm}^{2}{ }^{[38]}$

The performance of the $\mathrm{H}_{2} \mathrm{O}_{2}$ fuel cell in Figure 2 was improved by using $\mathrm{Ag}-\mathrm{Pb}$ alloy nanoparticles as the cathode, because $\mathrm{Ag}$ nanoparticles possess a higher specific surface area than the $\mathrm{Ag}$ plate and also the catalytic activity of the $\mathrm{Ag}$ nanoparticles cathode was enhanced by the addition of a foreign element to Ag metal. ${ }^{[39]}$ The higher power density, open- 


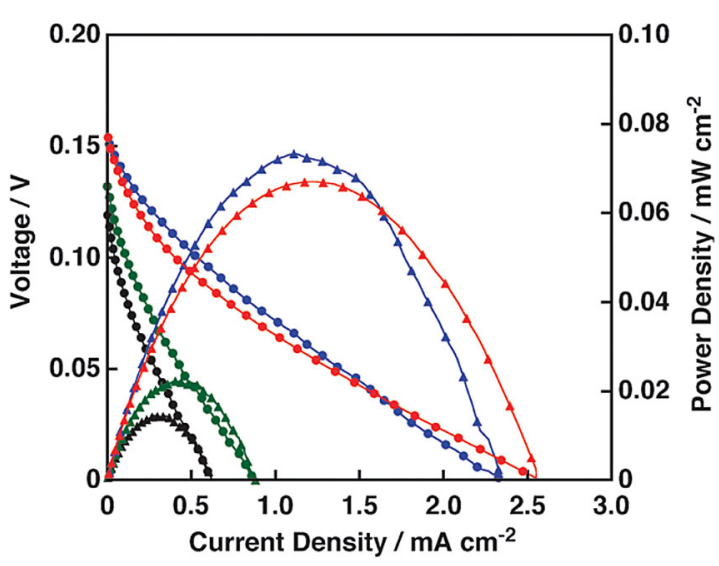

Figure 4. $I-V$ and $I-P$ curves of a one-compartment $\mathrm{H}_{2} \mathrm{O}_{2}$ fuel cell with a $\mathrm{Ag}$ or $\mathrm{Ag}-\mathrm{Pb}$ alloy cathode. Au anode: $1 \mathrm{M} \mathrm{NaOH}, 300 \mathrm{~mm} \mathrm{H}_{2} \mathrm{O}_{2}$. Black: $\mathrm{Ag}$, green: $\mathrm{Ag} / \mathrm{Pb}=6: 4$, red: $\mathrm{Ag} / \mathrm{Pb}=7: 3$, blue: $\mathrm{Ag} / \mathrm{Pb}=9: 1 .^{[39]}$

circuit potential $(0.16 \mathrm{~V})$, and short-circuit current were obtained by employing $\mathrm{Ag}-\mathrm{Pb}$ alloys as cathodes $(\mathrm{Ag} / \mathrm{Pb}=9: 1$, $7: 3,6: 4$ in Figure 4). ${ }^{[39]}$ Such highly active cathode materials for $\mathrm{H}_{2} \mathrm{O}_{2}$ reduction would be beneficial not only for other types of fuel cells using $\mathrm{H}_{2} \mathrm{O}_{2}$ as the oxidant but also those using $\mathrm{O}_{2}$, because the four-electron reduction of $\mathrm{O}_{2}$ is sometimes accompanied by two-electron reduction of $\mathrm{O}_{2}$ to produce peroxide species.

A two-compartment $\mathrm{H}_{2} \mathrm{O}_{2}$ fuel cell composed of a Pt/C cathode and a carbon paper (CP) anode deposited with nanonickel metal (Ni/CP), separated by a Nafion-117 membrane, was reported by using an acidic $\mathrm{H}_{2} \mathrm{O}_{2}$ solution $\left(1.5 \mathrm{M} \mathrm{H}_{2} \mathrm{SO}_{4}+2.0 \mathrm{M}\right.$ $\left.\mathrm{H}_{2} \mathrm{O}_{2}\right)$ as the catholite and a basic $\mathrm{H}_{2} \mathrm{O}_{2}$ solution $(6.0 \mathrm{M} \mathrm{NaOH}+$ $1.0 \mathrm{M} \mathrm{H}_{2} \mathrm{O}_{2}$ ) as the anolite; this cell afforded an OCP of $0.90 \mathrm{~V}$ and a power density of $3.9 \mathrm{~mW} \mathrm{~cm}^{-2}$. ${ }^{[46]}$ The peak power density was as high as $58.4 \mathrm{~mW} \mathrm{~cm}^{-2}$ at $60^{\circ} \mathrm{C}$ upon using $4.0 \mathrm{M}$ $\mathrm{KOH}+1.0 \mathrm{M} \mathrm{H}_{2} \mathrm{O}_{2}$ as the fuel and $2.0 \mathrm{M} \mathrm{H}_{2} \mathrm{SO}_{4}+2.0 \mathrm{M} \mathrm{H}_{2} \mathrm{O}_{2}$ as the oxidant. ${ }^{[46]}$ However, it is highly desired to develop a onecompartment $\mathrm{H}_{2} \mathrm{O}_{2}$ cell by using the same $\mathrm{H}_{2} \mathrm{O}_{2}$ solution under acidic conditions to combine the production of $\mathrm{H}_{2} \mathrm{O}_{2}$ through the two-electron reduction of $\mathrm{O}_{2}$, which is more efficient under acidic conditions. The key issue is the enhancement in the catalytic reactivity for $\mathrm{H}_{2} \mathrm{O}_{2}$ reduction.

The low output potentials of $\mathrm{H}_{2} \mathrm{O}_{2}$ fuel cells result from a large overpotential for $\mathrm{H}_{2} \mathrm{O}_{2}$ reduction at the cathode. ${ }^{[38]}$ Basic solutions impose thermodynamically unfavorable conditions for $\mathrm{H}_{2} \mathrm{O}_{2}$ reduction, for which a large overpotential is necessary. Thus, neutral to acidic solutions should be employed to improve the open-circuit potentials of $\mathrm{H}_{2} \mathrm{O}_{2}$ fuel cells.

In natural systems, iron porphyrin complexes are used as active sites of hydroperoxidases, which can efficiently catalyze the reduction of $\mathrm{H}_{2} \mathrm{O}_{2}$ under neutral $\mathrm{pH}$ conditions. ${ }^{[72-75]}$ Thus, the iron porphyrin and iron phthalocyanine complexes shown in Figure 5, which mimic the active sites of hydroperoxidases, were have been employed as cathode catalysts to improve the $\mathrm{H}_{2} \mathrm{O}_{2}$ reduction activity under acidic conditions. ${ }^{[40]}$

The OCP was improved to $0.55 \mathrm{~V}$ by using iron(III) phthalocyanine (Pc) Dok? chloride supported on a glassy carbon as the cathode of a $\mathrm{H}_{2} \mathrm{O}_{2}$ fuel cell working at $\mathrm{pH} 3$ (a)

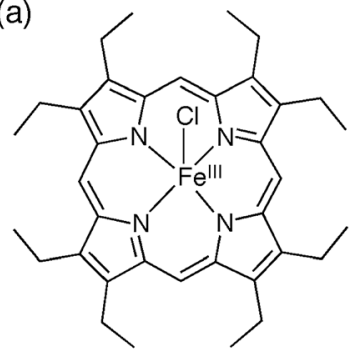

(c)

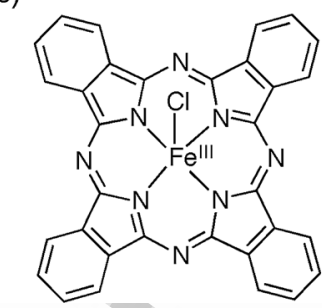

Figure 5. Chemical structures of porphyrin and phthalocyanine iron(III) complexes similar to the active-site structures of hydroperoxidases as candidates of cathodes of a $\mathrm{H}_{2} \mathrm{O}_{2}$ fuel cell. a) [Fe" $\left.{ }^{\prime \prime \prime}(\mathrm{OEP}) \mathrm{Cl}\right]$, b) [Fe"'(TPP)Cl], and c) $\left[\mathrm{Fe}{ }^{\mathrm{III}}(\mathrm{Pc}) \mathrm{Cl}\right]{ }^{[40]}$

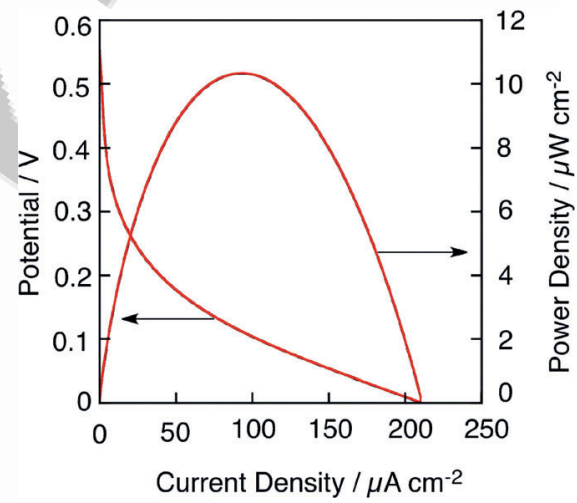

Figure 6. $I-V$ and $I-P$ curves of a one-compartment $\mathrm{H}_{2} \mathrm{O}_{2}$ fuel cell with a $\mathrm{Ni}$ anode and a [Fe"l' $(\mathrm{Pc}) \mathrm{Cl}]$ cathode. Performance tests were conducted in an acetate buffer containing $300 \mathrm{mM} \mathrm{H}_{2} \mathrm{O}_{2}$ at $\mathrm{pH} 3.0^{[40]}$

(Figure 6). ${ }^{[0]}$ The catalytic activities of the iron complexes for $\mathrm{H}_{2} \mathrm{O}_{2}$ reduction were evaluated by cyclic voltammetry (CV) measurements of $\mathrm{H}_{2} \mathrm{O}_{2}$. The iron complexes were mounted on glassy carbon electrodes to be used as the working electrodes in aqueous acetate buffer containing $\mathrm{H}_{2} \mathrm{O}_{2}(\mathrm{pH} 4,3 \mathrm{~mm}) \cdot{ }^{[40]}$ In the presence of $\mathrm{H}_{2} \mathrm{O}_{2}$, catalytic currents with the Fe complexes in cathodic sweeps were observed, which indicated that they could act as catalysts for $\mathrm{H}_{2} \mathrm{O}_{2}$ reduction in acidic media. ${ }^{[40]}$ The onset potential for $\mathrm{H}_{2} \mathrm{O}_{2}$ reduction on electrodes with [Fe"I $(\mathrm{Pc}) \mathrm{Cl}$ ] was $0.5 \mathrm{~V}$, which is more positive than that observed with either [Fe"I $(\mathrm{OEP}) \mathrm{Cl}](\mathbf{\square} \mathrm{OEP}=$ please define $\mathbf{\square})$ or $\left[\mathrm{Fe}^{\mathrm{III}}(\mathrm{TPP}) \mathrm{Cl}\right](0.2 \mathrm{~V})(\mathbf{\square} \mathrm{TPP}=$ please define $\mathbf{\square})$, which suggests that $\left[\mathrm{Fe} \mathrm{F}^{\mathrm{III}}(\mathrm{Pc}) \mathrm{Cl}\right]$ is the most promising cathode material for a $\mathrm{H}_{2} \mathrm{O}_{2}$ fuel cell operating under acidic solutions. ${ }^{[40]}$

Prussian blue [ferric ferrocyanide: $\left.\left(\mathrm{Fe}_{4}{ }^{\prime \prime \prime}\left[\mathrm{Fe}^{\prime \prime}(\mathrm{CN})_{6}\right]_{3}\right)\right]$ has been used for the cathode in a one-compartment $\mathrm{H}_{2} \mathrm{O}_{2}$ fuel cell under acidic conditions by using $0.10 \mathrm{M} \mathrm{HCl}$ and $0.50 \mathrm{M} \mathrm{H}_{2} \mathrm{O}_{2}{ }^{[41]}$ 


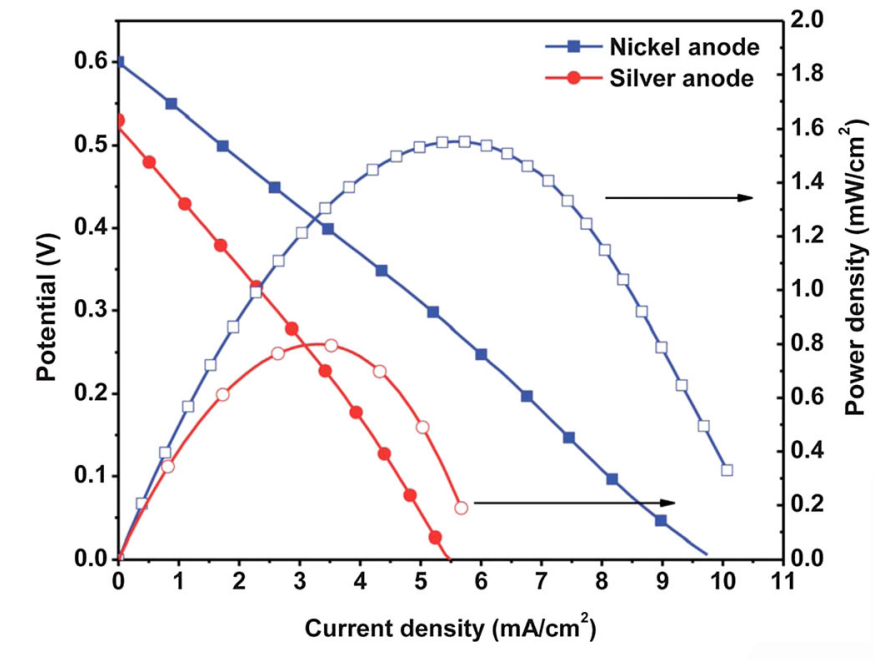

Figure 7. $I-V$ and $I-P$ curves of a one-compartment $\mathrm{H}_{2} \mathrm{O}_{2}$ fuel cell with nickel and silver anodes and unsupported Prussian blue coated on carbon paper as the cathode. Performance tests were performed under acidic conditions by using $0.10 \mathrm{M} \mathrm{HCl}$ and $0.50 \mathrm{M} \mathrm{H}_{2} \mathrm{O}_{2}{ }^{[41]}$

An OCP of $0.60 \mathrm{~V}$ and a maximum power density of $1.55 \mathrm{~mW} \mathrm{~cm}^{-2}$ were obtained to maintain stable long-term operation in acidic media (Figure 7)..$^{[41]}$

A higher OCP of $0.8 \mathrm{~V}$ for a $\mathrm{H}_{2} \mathrm{O}_{2}$ fuel cell with the one-compartment structure was obtained by using the polynuclear cyanide complex $\mathrm{Fe}_{3}{ }_{3}\left[\mathrm{CO}^{\mathrm{III}}(\mathrm{CN})_{6}\right]_{2}$ and $\mathrm{Ni}$ mesh as the cathode and anode, respectively, under acidic conditions at $\mathrm{pH} 1$ (Figure 8). ${ }^{[42]}$ The maximum power density of the fuel cell was $1.0 \mathrm{~mW} \mathrm{~cm}^{-2} \cdot{ }^{[42]}$ The presence of nitrogen-bound $\mathrm{Fe}^{2+}$ ions in the cathode was found to be important for the higher performance of the one-compartment $\mathrm{H}_{2} \mathrm{O}_{2}$ fuel cell. ${ }^{[66]}$ The stability of the $\mathrm{H}_{2} \mathrm{O}_{2}$ fuel cell was improved by replacing the carbon cloth electrode with a carbon-paste electrode containing $25 \mathrm{wt} \% \mathrm{Fe}_{3}{ }_{3}\left[\mathrm{CO} \mathrm{Co}^{\mathrm{III}}(\mathrm{CN})_{6}\right]_{2}$. Severe deactivation of the cell performance resulting from detachment of $\mathrm{Fe}^{\mathrm{III}}{ }_{3}\left[\mathrm{CO}^{\mathrm{III}}(\mathrm{CN})_{6}\right]_{2}$ from the carbon cloth was suppressed. ${ }^{[42]}$ After 50 cycles, only a subtle change was observed in the OCP, and more than $80 \%$ of the initial maximum power density was maintained $\square$ ok? a(Figure $8 b) .^{[42]}$

The maximum power density of a $\mathrm{H}_{2} \mathrm{O}_{2}$ fuel cell was improved by employing a pyrazine-bridged $\mathrm{Fe}^{\mathrm{C}}\left[\mathrm{M}^{\mathrm{C}}(\mathrm{CN})_{4}\right]$ complex $\left(\mathrm{M}^{\mathrm{C}}=\mathrm{Pt}^{2+}\right.$ and $\left.\mathrm{Pd}^{2+}\right)$ with a $3 \mathrm{D}$ porous structure as the as the cathode and a nickel mesh as the anode operating in $0.30 \mathrm{M}$ $\mathrm{H}_{2} \mathrm{O}_{2}$ at pH 1.0 (Figure 9). ${ }^{[44]}$ The power density of the $\mathrm{H}_{2} \mathrm{O}_{2}$ fuel cell with pyrazine-bridged $\mathrm{Fe}\left[\mathrm{Pt}(\mathrm{CN})_{4}\right]$ exceeded $4 \mathrm{~mW} \mathrm{~cm}^{-2}$. ${ }^{[44]}$ In contrast, $\mathrm{H}_{2} \mathrm{O}_{2}$ fuel cells with pyrazine-bridged $\mathrm{M}^{\mathrm{N}}\left[\mathrm{Pt}(\mathrm{CN})_{4}\right]$ $\left(\mathrm{M}^{\mathrm{N}}=\mathrm{CO}^{2+}\right.$ and $\left.\mathrm{Mn}^{2+}\right)$ as the cathodes showed power densities lower than $0.01 \mathrm{~mW} \mathrm{~cm}^{-2}$, which suggests that $\mathrm{Fe}^{2+}$ ions play a crucial role and that the $\mathrm{Pt}^{2+}$ ions are not important for achieving a high power density. ${ }^{[4]}$

The OCP and power density of the $\mathrm{H}_{2} \mathrm{O}_{2}$ fuel cell with heattreated $\left[\mathrm{Fe}^{\prime \prime}\left(\mathrm{H}_{2} \mathrm{O}\right)_{2}\right]_{3}\left[\mathrm{Co}{ }^{\prime \prime \prime}(\mathrm{CN})_{6}\right]_{2}$ at $60^{\circ} \mathrm{C}$ were much improved by adding $\mathrm{Sc}^{3+}$ ions into the aqueous $\mathrm{H}_{2} \mathrm{O}_{2}$ fuel at concentrations of $50 \mathrm{~mm}$ or higher. The OCP value increased in proportion to the concentration of $\mathrm{Sc}^{3+}$ to reach a constant value of $(0.81 \pm$ 0.01) V (Figure 10). ${ }^{[43]}$ Additionally, the maximum power density

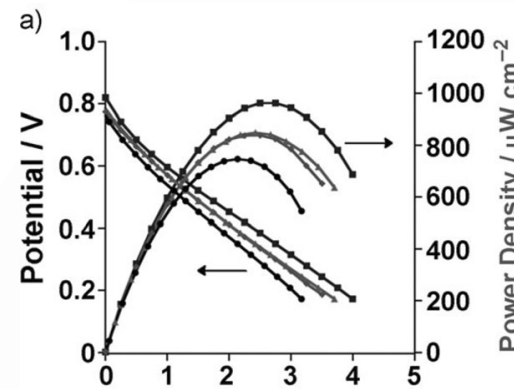

Current Density / $\mathrm{mA} \mathrm{cm} \mathrm{cm}^{-2}$

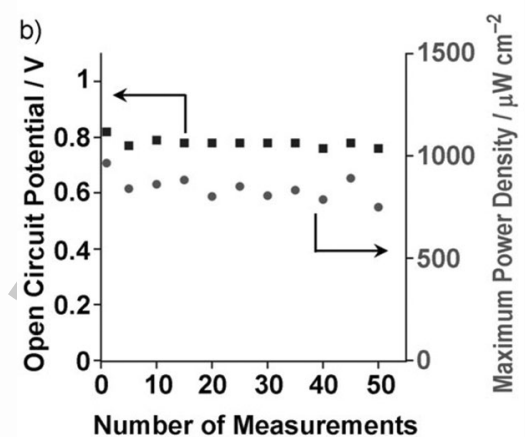

Figure 8. a) $I-V$ and $1--P$ curves of a one-compartment $\mathrm{H}_{2} \mathrm{O}_{2}$ fuel cell with a $\mathrm{Ni}$ anode and a carbon-paste electrode that was modified with $\mathrm{Fe}_{3}\left[\mathrm{Co}^{\prime \prime \prime}(\mathrm{CN})_{6}\right]_{2}$ after the 1 st $(\bullet)$, 5th $(\bullet), 25$ th $(\boldsymbol{\Delta})$, and 50th cycles $(\bullet)$. Performance tests were performed in an aqueous solution of $\mathrm{HClO}_{4}(\mathrm{pH} 1)$ that contained $\mathrm{H}_{2} \mathrm{O}_{2}(0.30 \mathrm{M})$ and $\mathrm{NaCl}(1.0 \mathrm{M})$. Currents and powers were normalized by the geometric surface area of the electrode. b) Changes in the opencircuit potential ( $\square$ ) and power density $(\bullet)$ after repeated measurements of the $\mathrm{H}_{2} \mathrm{O}_{2}$ fuel cell. ${ }^{[42]}$

exceeded $(9.9 \pm 0.13) \mathrm{mW} \mathrm{cm}^{-2}$ by increasing the concentration of $\mathrm{Sc}^{3+}$ ions to $120 \mathrm{~mm}$ (Figure 10). This value is larger than the value $\left[(7.5 \pm 0.05) \mathrm{mW} \mathrm{cm}^{-2}\right]$ obtained with nitric acid $(\mathrm{pH} 1.0){ }^{[43]}$

The effect of other Lewis acids upon the performance of $\mathrm{H}_{2} \mathrm{O}_{2}$ fuel cells was also examined. The performance was improved by the addition of trivalent $\mathrm{Yb}^{3+}$ and $\mathrm{Y}^{3+}$ ions $(100 \mathrm{~mm})$; however, the obtained OCPs and power densities remained at low levels, $<0.5 \mathrm{~V}$ and $<1.1 \mathrm{~mW} \mathrm{~cm}^{-2}$. ${ }^{[43]}$ The most effective divalent ion was $\mathrm{Ca}^{2+}$; however, the OCP and power density for the $\mathrm{H}_{2} \mathrm{O}_{2}$ fuel cell with the use of an aqueous $\mathrm{H}_{2} \mathrm{O}_{2}$ fuel containing $\mathrm{Ca}^{2+}$ ions were as low as $(0.47 \pm 0.02) \mathrm{V}$ and $(0.47 \pm 0.05) \mathrm{mW} \mathrm{cm}^{-2}$, respectively. Thus, the strongest Lewis acid among the metal ions, that is, $\mathrm{Sc}^{3+}$ ions, ${ }^{[76-78]}$ acted as the most effective additive for improving the performance of the $\mathrm{H}_{2} \mathrm{O}_{2}$ fuel cell in terms of both OCP and power density. ${ }^{[43]}$ In addition, $\mathrm{H}_{2} \mathrm{O}_{2}$ decomposition in the reaction solution was efficiently avoided by the addition of $\mathrm{Sc}^{3+}$ ions, which led to high power densities and durability, ${ }^{[43]}$ because $\mathrm{Sc}^{3+}$ ions have been reported to bind with $\mathrm{H}_{2} \mathrm{O}_{2}$ to stabilize it. ${ }^{[79]}$ Only a small decrease in the output potential $(40 \mathrm{mV})$ was observed under operation for 90 min by using aqueous $\mathrm{H}_{2} \mathrm{O}_{2}$ containing $100 \mathrm{~mm}$ $\mathrm{Sc}^{3+}$ ions as the fuel, whereas the output potential decreased to $0 \mathrm{~V}$ within $5 \mathrm{~min}$ without the $\mathrm{Sc}^{3+}$ ions. ${ }^{[43]}$ 

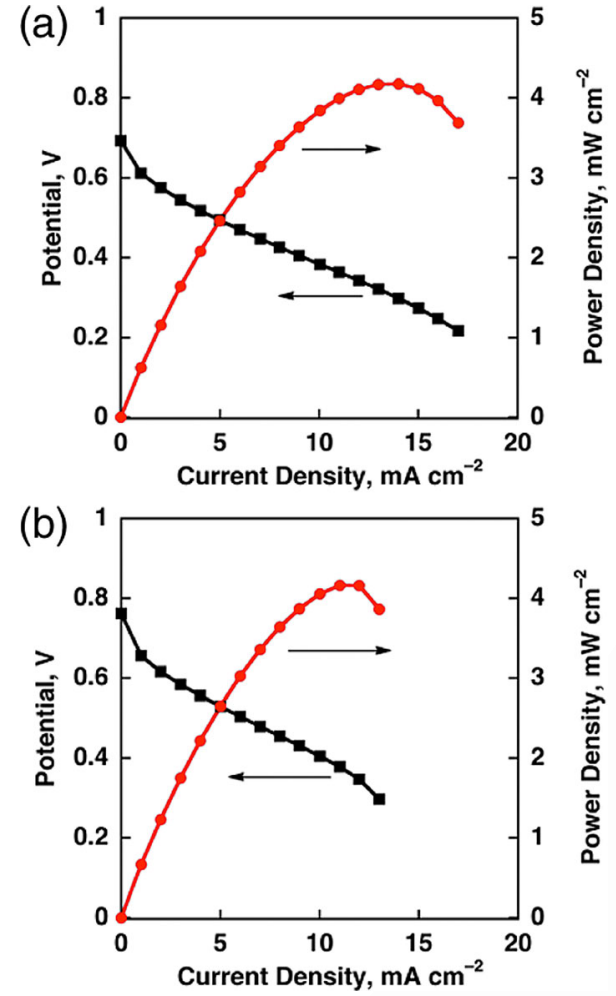

Figure 9. a) $I-V(\square)$ and $I-P(\bullet)$ curves of a one-compartment $\mathrm{H}_{2} \mathrm{O}_{2}$ fuel cell with a nickel anode and a carbon-cloth electrode modified with a pyrazinebridged $\mathrm{Fe}\left[\mathrm{M}^{\mathrm{C}}(\mathrm{CN})_{4}\right]$ complex $\left[\mathrm{M}^{\mathrm{C}}=\mathrm{Pt}^{2+}\right.$ (a) and $\left.\mathrm{Pd}^{2+}(\mathrm{b})\right]$. Performance tests were conducted in an aqueous solution of $\mathrm{HClO}_{4}(\mathrm{pH} 1)$ that contained $\mathrm{H}_{2} \mathrm{O}_{2}$ $(0.30 \mathrm{M})$ and $\mathrm{NaCl}(1.0 \mathrm{M})$. Currents and powers were normalized by the geometric surface area of the electrode. ${ }^{[44]}$

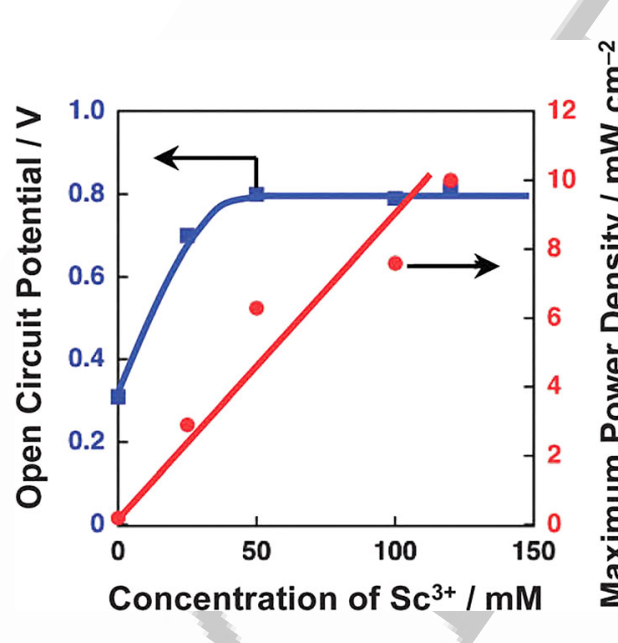

Figure 10. Plots of the open-circuit potentials and maximum power densities versus concentrations of $\mathrm{Sc}\left(\mathrm{NO}_{3}\right)_{3}$ for a one-compartment $\mathrm{H}_{2} \mathrm{O}_{2}$ fuel cell with a $\mathrm{Ni}$ anode and a carbon cloth electrode modified with

$\left[\mathrm{Fe}^{\prime \prime}\left(\mathrm{H}_{2} \mathrm{O}\right)_{2}\right]_{3}\left[\mathrm{Co} \text { "II' }(\mathrm{CN})_{6}\right]_{2}$ in an aqueous solution containing $0.30 \mathrm{M} \mathrm{H}_{2} \mathrm{O}_{2}$ and $\mathrm{Sc}\left(\mathrm{NO}_{3}\right)_{3} \cdot{ }^{[43]}$

\section{Production of Hydrogen Peroxide from Water and Oxygen as a Solar Fuel}

The generation of $\mathrm{H}_{2} \mathrm{O}_{2}$ by the photoreduction of $\mathrm{O}_{2}$ is an interesting approach, because photoreduction of $\mathrm{O}_{2}$ requires less energy than $\mathrm{H}_{2}$ generation. On the one hand, the redox potential of $2 \mathrm{H}^{+}+2 \mathrm{e}^{-}=\mathrm{H}_{2}$ is $0 \mathrm{~V}$ versus $\mathrm{NHE}$; on the other hand, that of $\mathrm{O}_{2}+2 \mathrm{H}^{+}+2 \mathrm{e}^{-}=\mathrm{H}_{2} \mathrm{O}_{2}$ is $0.68 \mathrm{~V}$ versus $\mathrm{NHE}$, which suggests that a wide variety of materials can be used as an electron source. For example, oxalate is used as an electron source for efficient photocatalytic $\mathrm{H}_{2} \mathrm{O}_{2}$ production. However, utilization of water as an electron source is still a challenge.

$\mathrm{H}_{2} \mathrm{O}_{2}$ was produced by electrocatalytic $\mathrm{O}_{2}$ reduction by employing a two-compartment cell connected to an agar salt bridge. ${ }^{[39]}$ Glassy carbon electrodes modified with the cobalt porphyrins shown in Figure 11 were used as electrocatalysts,<smiles>c1ccc(-c2c3ccc4c(-c5ccccc5)c5c(-c6ccccc6)c6ccc7n6c(-c6ccccc6)c(n34)n5n7n3cccc23)cc1</smiles>

[Co(TPP)]

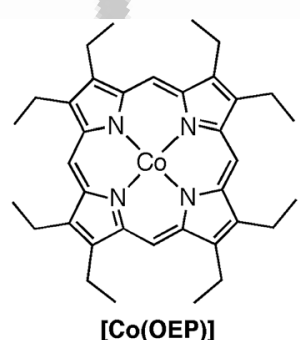

[Co(OEP)]

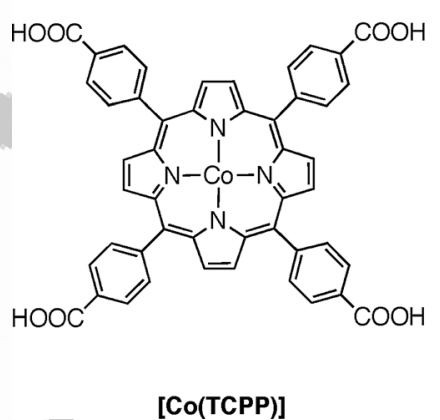

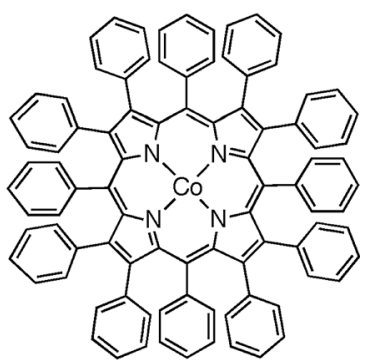

[Co(DPP)]
Figure 11. Structures of Co porphyrin catalysts for two-electron reduction of $\mathrm{O}_{2}{ }^{[39]}$

because cobalt porphyrins are well known to act as selective catalysts for the two-electron reduction of $\mathrm{O}_{2}$ to produce $\mathrm{H}_{2} \mathrm{O}_{2} \cdot{ }^{\left[{ }^{[9-89]}\right.}$ Among the Co porphyrins evaluated, [Co(TCPP)] (

TCPP = please define $\square$ ) showed the highest onset potential of $0.3 \mathrm{~V}$ for catalytic $\mathrm{O}_{2}$ reduction. On the basis of these results, $[\mathrm{Co}(\mathrm{TCPP})]$ and $\mathrm{Pt}$ wire electrodes were connected to a conventional Si photovoltaic solar cell that generated electrical power of $0.5 \mathrm{~V}$ at $2.5 \mathrm{~mA} .^{[39]}$ After running for $11 \mathrm{~h}$, the amount of $\mathrm{H}_{2} \mathrm{O}_{2}$ produced reached $1.46 \times 10^{-5} \mathrm{~mol}^{[39]} \mathrm{H}_{2} \mathrm{O}_{2}$ generation was observed by the reduction of $\mathrm{O}_{2}$ by using a conventional photovoltaic solar cell, ${ }^{[39]}$ although it is still necessary to improve the electrocatalytic behavior and the structures of the cell and electrode for better performance.

It has been shown that $\mathrm{H}_{2} \mathrm{O}_{2}$ can be produced by combining photoinduced electron transfer from Ru" complexes ([Ru"L $]^{2+}$ ) to $\mathrm{O}_{2}$ and catalytic water oxidation by $\left[\mathrm{Ru}^{\mathrm{III}} \mathrm{L}\right]^{3+}$ with a water oxidation catalyst (WOC), as shown in Scheme 1. ${ }^{[00]}$

Photoinduced electron transfer from the excited state of $\left[R u^{\prime \prime} \mathrm{L}\right]^{2+}$ to $\mathrm{O}_{2}$ produces $\left[\mathrm{Ru}^{\prime \prime \prime} \mathrm{L}\right]^{3+}$ and $\mathrm{O}_{2}{ }^{-}$, the latter of which is protonated in the presence of acids to produce $\mathrm{HO}_{2}$, and 


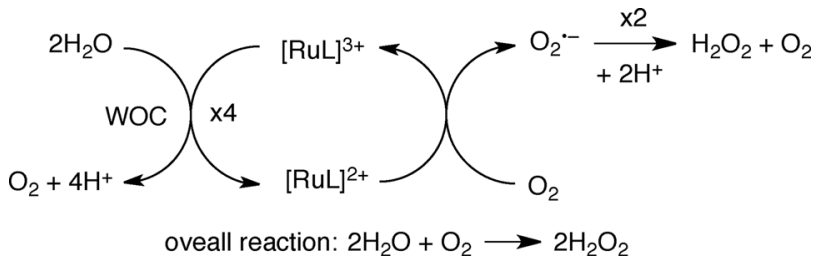

Scheme 1.

the disproportionation of $\mathrm{HO}_{2}$ yields $\mathrm{H}_{2} \mathrm{O}_{2}$ and $\mathrm{O}_{2} \cdot{ }^{[90,91]}$ Various metal complexes and metal nanoparticles are known to catalyze water oxidation by $\left[\mathrm{Ru}^{\mathrm{III}} \mathrm{L}\right]^{3+}$ to produce $\mathrm{O}_{2}{ }^{\left[{ }^{[92-103]}\right.}$ Thus, the overall reaction is the photocatalytic oxidation of $\mathrm{H}_{2} \mathrm{O}$ by $\mathrm{O}_{2}$ to produce $\mathrm{H}_{2} \mathrm{O}_{2}$, in which photocatalytic two-electron reduction of $\mathrm{O}_{2}$ and the catalytic four-electron oxidation of $\mathrm{H}_{2} \mathrm{O}$ proceed. ${ }^{[83]}$ Upon using $\left[\mathrm{Ru}^{\prime \prime}\left(\mathrm{Me}_{2} \text { phen }\right)_{3}\right]^{2+}\left(\mathrm{Me}_{2}\right.$ phen =4,7-dimeth$\mathrm{yl}-1,10$-phenanthroline $)$ and $\left[\mathrm{Co}^{\prime \prime \prime}\left(\mathrm{Cp}^{*}\right)(\mathrm{bpy})\left(\mathrm{H}_{2} \mathrm{O}\right)\right]^{2+}\left(\mathrm{Cp}^{*}=\eta^{5}-\right.$ pentamethylcyclopentadienyl; bpy $=2,2^{\prime}$-bipyridine) as the photocatalyst and WOC, respectively, in the presence of $\mathrm{Sc}\left(\mathrm{NO}_{3}\right)_{3}$ in water, the optimized quantum yield of the photocatalytic production of $\mathrm{H}_{2} \mathrm{O}_{2}$ at $\lambda=450 \mathrm{~nm}$ was determined to be $37 \% .{ }^{[90]}$ The conversion efficiency from solar energy to chemical energy was determined to be $0.25 \% .{ }^{[90]}$ Photocatalytic $\mathrm{H}_{2} \mathrm{O}_{2}$ production proceeded through electron transfer from photoexcited $\left[\mathrm{Ru}^{\prime \prime}\left(\mathrm{Me}_{2} \text { phen }\right)_{3}\right]^{2+}$ to $\mathrm{O}_{2}$ to produce $\left[\mathrm{Ru}^{\mathrm{III}}\left(\mathrm{Me}_{2} \text { phen }\right)_{3}\right]^{3+}$ and $\mathrm{O}_{2} .^{-}$binding to $\mathrm{Sc}^{3+}{ }^{[90]}$ The disproportionation of $\mathrm{O}_{2}{ }^{-}-\mathrm{Sc}^{3+}$ in water yielded $\mathrm{H}_{2} \mathrm{O}_{2}$, whereas 4 equivalents of $\left[\mathrm{Ru}^{\text {III }}\left(\mathrm{Me}_{2} \text { phen }\right)_{3}\right]^{3+}$ oxidized $\mathrm{H}_{2} \mathrm{O}$ to $\mathrm{O}_{2}$ in the presence of the WOC. ${ }^{[90]}$

Graphitic carbon nitride with electron-deficient aromatic diimide units $\left(\mathrm{g}-\mathrm{C}_{3} \mathrm{~N}_{4} / \mathrm{PDI}\right.$; $\mathrm{PDI}=$ pyromellitic diimide) was reported to work as a photocatalyst for $\mathrm{H}_{2} \mathrm{O}_{2}$ production from $\mathrm{H}_{2} \mathrm{O}$ and $\mathrm{O}_{2} \cdot{ }^{[104]}$ However, the amount of $\mathrm{H}_{2} \mathrm{O}_{2}$ formed by photoirradiation for $48 \mathrm{~h}$ was only $30 \mu \mathrm{mol} .{ }^{[104]}$

The production of $\mathrm{H}_{2} \mathrm{O}_{2}$ from $\mathrm{H}_{2} \mathrm{O}$ and $\mathrm{O}_{2}$ as a solar fuel was also performed by using $\mathrm{NiFe}_{2} \mathrm{O}_{4}$ nanoparticles composed of earth-abundant metals as a $W_{O C} C^{[105]}$ in the presence of $\left[\mathrm{Ru}^{\prime \prime}\left(\mathrm{Me}_{2} \text { phen }\right)_{3}\right]^{2+}$ and $\mathrm{Sc}\left(\mathrm{NO}_{3}\right)_{3}$ under visible-light irradiation $(\lambda>420 \mathrm{~nm}) .{ }^{[106]}$ The $\mathrm{NiFe}_{2} \mathrm{O}_{4}$ catalyst was reused after $\mathrm{H}_{2} \mathrm{O}_{2}$ production ceased due to the decomposition of the photocatalyst by repeated addition of an aqueous solution of $\left[\mathrm{Ru}^{\prime \prime}\left(\mathrm{Me}_{2} \text { phen }\right)_{3}\right]^{2+}$ to the reaction suspension. The concentration of $\mathrm{H}_{2} \mathrm{O}_{2}$ after repeated reactions reached as high as $3.3 \mathrm{~mm}$, which is indicative of the high stability of the nanoparticles as a WOC (Figure 12b). ${ }^{[106]}$ The initial rates of $\mathrm{H}_{2} \mathrm{O}_{2}$ production were increased 22- and 33-fold by employing smaller $\mathrm{NiFe}_{2} \mathrm{O}_{4}$ nanoparticles with diameters of 120 and $91 \mathrm{~nm}$, respectively, relative to the initial rate of $\mathrm{H}_{2} \mathrm{O}_{2}$ production by using large $\mathrm{NiFe}_{2} \mathrm{O}_{4}$, with a diameter of $1300 \mathrm{~nm}$ (Figure 12a). ${ }^{[106]}$ This enhanced reactivity resulted from the high specific surface area of the smaller catalyst. ${ }^{[106]}$

Various heteropolynuclear cyanide metal complexes containing different metal ions, $\mathrm{Co}_{3}\left[\mathrm{Fe}(\mathrm{CN})_{6}\right]_{2}, \mathrm{Co}_{3}\left[\mathrm{Co}(\mathrm{CN})_{6}\right]_{2}$, $\mathrm{Cu}_{3}\left[\mathrm{Co}(\mathrm{CN})_{6}\right]_{2}, \quad \mathrm{Co}\left[\mathrm{Ni}(\mathrm{CN})_{4}\right], \quad \mathrm{Fe}_{3}\left[\mathrm{Cr}(\mathrm{CN})_{6}\right]_{2}, \quad \mathrm{Mn}_{3}\left[\mathrm{Fe}(\mathrm{CN})_{6}\right]_{2}$, $\mathrm{Co}_{3}\left[\mathrm{Mn}(\mathrm{CN})_{6}\right]_{2}, \quad \mathrm{Co}_{3}\left[\mathrm{Fe}(\mathrm{CN})_{6}\right]_{2}, \quad \mathrm{Co}\left[\mathrm{Pd}(\mathrm{CN})_{4}\right]$, and $\mathrm{Co}\left[\mathrm{Pt}(\mathrm{CN})_{4}\right]$, were also used for water oxidation in the photocatalytic pro- (a)

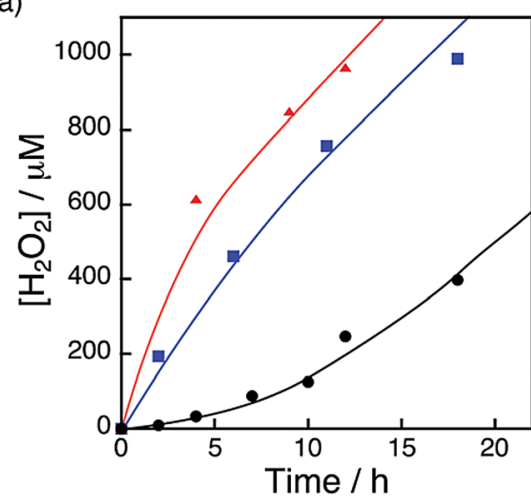

b)

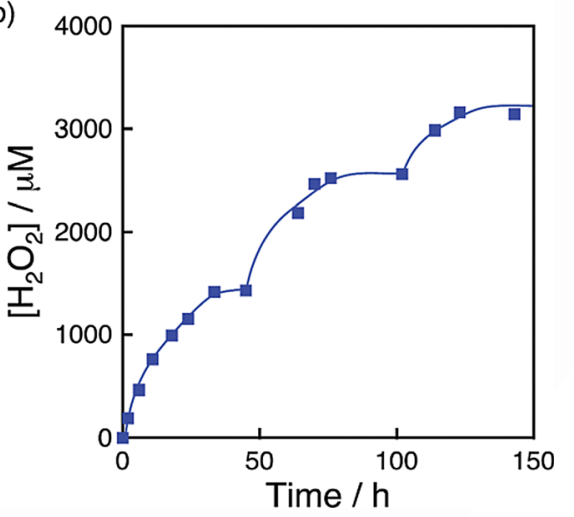

Figure 12. a) Time course of $\mathrm{H}_{2} \mathrm{O}_{2}$ production under visible-light irradiation $(\lambda>420 \mathrm{~nm})$ of $\left[\mathrm{Ru}^{\prime \prime}\left(\mathrm{Me}_{2} \mathrm{phen}\right)_{3}\right]^{2+}(200 \mu \mathrm{M})$ in the presence of $\mathrm{Sc}\left(\mathrm{NO}_{3}\right)_{3}$ $(100 \mathrm{~mm})$ and $\mathrm{NiFe}_{2} \mathrm{O}_{4}\left(0.17 \mathrm{~g} \mathrm{~L}^{-1}\right)$ with diameters of $1300 \mathrm{~nm}(\bullet), 120 \mathrm{~nm}$ $(\boldsymbol{\Xi})$, and $91 \mathrm{~nm}(\boldsymbol{\Delta})$ in $\mathrm{O}_{2}$-saturated $\mathrm{H}_{2} \mathrm{O}\left(3.0 \mathrm{~mL},\left[\mathrm{O}_{2}\right]=1.2 \mathrm{~mm}\right)$. b) Time course of $\mathrm{H}_{2} \mathrm{O}_{2}$ production in the presence of $\mathrm{NiFe}_{2} \mathrm{O}_{4}\left(0.17 \mathrm{~g} \mathrm{~L}^{-1}\right)$ and $\mathrm{Sc}\left(\mathrm{NO}_{3}\right)_{3}(100 \mathrm{~mm})$ under visible-light irradiation $(\lambda>420 \mathrm{~nm})$ of

$\left[\mathrm{Ru}^{\prime \prime}\left(\mathrm{Me}_{2} \text { phen }\right)_{3}\right]^{2+}(200 \mu \mathrm{M})$ in $\mathrm{O}_{2}$-saturated $\mathrm{H}_{2} \mathrm{O}\left(3.0 \mathrm{~mL},\left[\mathrm{O}_{2}\right]=1.2 \mathrm{~mm}\right)$. $\left[\mathrm{Ru}^{\prime \prime}\left(\mathrm{Me}_{2} \mathrm{phen}\right)_{3}\right]^{2+}$ was added twice to the reaction suspension after 50 and $100 \mathrm{~h}$ of photoirradiation. The amount of $\left[\mathrm{Ru}^{\prime \prime}\left(\mathrm{Me}_{2} \text { phen }\right)_{3}\right]^{2+}$ added each time at 50 and $100 \mathrm{~h}$ to the reaction suspension was calculated in terms of the concentration increase of $200 \mu \mathrm{M} .{ }^{[106]}$

duction of $\mathrm{H}_{2} \mathrm{O}_{2}$ from $\mathrm{H}_{2} \mathrm{O}$ and $\mathrm{O}_{2}$ in an aqueous solution containing $\left\{\left[\mathrm{Ru}^{\prime \prime}\left(\mathrm{Me}_{2} \text { phen }\right)\right]_{3}\right\}^{2+}$ and $\mathrm{Sc}\left(\mathrm{NO}_{3}\right)_{3}$ under visible-light irradiation with a xenon lamp by using a UV light cut filter $(\lambda>$ $420 \mathrm{~nm}) \cdot{ }^{[107]}$ Among the various heteropolynuclear cyanide complexes, the highest catalytic reactivity was obtained with $\mathrm{Fe}_{3}\left[\mathrm{Co}(\mathrm{CN})_{6}\right]_{2}{ }^{[107]}$ The catalytic reactivity was further enhanced by using the heteropolynuclear cyanide complexes $\left(\mathrm{Fe}_{x} \mathrm{Co}_{1-x}\right)_{3}\left[\mathrm{Co}(\mathrm{CN})_{6}\right]_{2}(x=0,0.10,0.50,0.75,0.90$, and 1$)$ shown in Figure 13.

The catalytic activity was maximized if the Fe/Co ratio in the $\left(\mathrm{Fe}_{x} \mathrm{Co}_{1-x}\right)$ moiety of $\left(\mathrm{Fe}_{x} \mathrm{Co}_{1-x}\right)_{3}\left[\mathrm{Co}(\mathrm{CN})_{6}\right]_{2}$ was $0.75 .^{[107]}$ WOCs with a larger Fe ratio would have more active sites for water oxidation, whereas a complex with a smaller Fe ratio would stabilize the high-valent metal ions generated during the photocatalytic reaction. ${ }^{[107]}$ The optimized ratio of $\mathrm{Fe}$ in $\left(\mathrm{Fe}_{x} \mathrm{Co}_{1-x}\right)_{3}\left[\mathrm{Co}(\mathrm{CN})_{6}\right]_{2}(x=0.75)$ was obtained by the balance of the two opposite effects of Fe on the water oxidation reaction. ${ }^{[107]}$

If water oxidation and $\mathrm{O}_{2}$ reduction were performed in a one-compartment cell as described above, the oxidation of $\mathrm{H}_{2} \mathrm{O}_{2}$ inevitably competed with water oxidation in the presence 


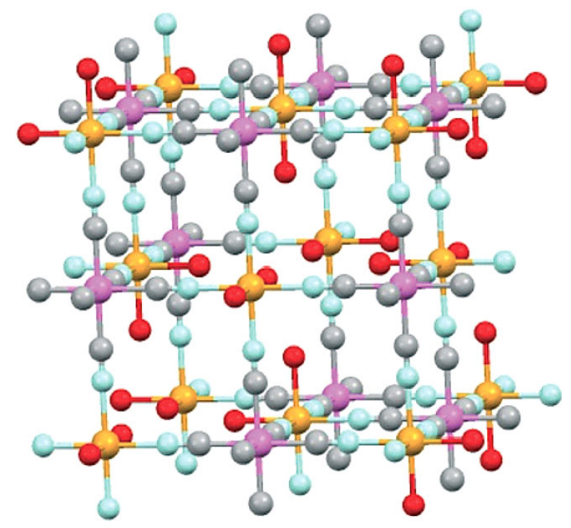

Figure 13. A schematic drawing of $\left(\mathrm{Fe}_{x} \mathrm{Co}_{1-x}\right)_{3}\left[\mathrm{Co}(\mathrm{CN})_{6}\right]_{2}$, for which $x=0$, $0.10,0.50,0.75,0.90$, and 1 . lons are color coded: $\mathrm{N}$-bound $\mathrm{Co}^{\prime \prime}$ and $\mathrm{Fe}^{\prime \prime}$ (orange), C-bound Co' (pink), C (gray), N (blue), and O (red). ${ }^{\text {[107] }}$

of a WOC to prevent the production of $\mathrm{H}_{2} \mathrm{O}_{2}$ at higher concentrations. Thus, the photocatalytic production of $\mathrm{H}_{2} \mathrm{O}_{2}$ from $\mathrm{H}_{2} \mathrm{O}$ and $\mathrm{O}_{2}$ was performed by using a two-compartment cell by employing a semiconductor photocatalyst anode in one cell and a carbon mesh cathode in an $\mathrm{O}_{2}$-saturated aqueous solution containing $\mathrm{Ru}$ complexes and $\mathrm{Sc}\left(\mathrm{NO}_{3}\right)_{3}$ in the other cell to achieve higher concentrations of $\mathrm{H}_{2} \mathrm{O}_{2}$ than that obtained with a one-compartment cell. ${ }^{[108]} \mathrm{A}$ schematic drawing of the twocompartment cell is depicted in Figure 14, for which $\mathrm{WO}_{3}$ or

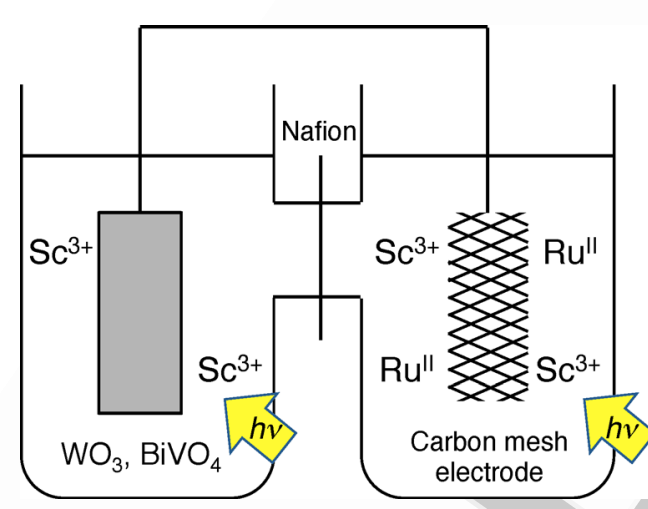

Figure 14. Schematic drawing of a two-compartment cell for the photocatalytic production of $\mathrm{H}_{2} \mathrm{O}_{2}$ from $\mathrm{H}_{2} \mathrm{O}$ and $\mathrm{O}_{2}$ under visible-light irradiation. ${ }^{\text {[108] }}$

$\mathrm{BiVO}_{4}$ was used as the anode ${ }^{[109,110]}$ for the photooxidation of water and a carbon mesh cathode was employed for photoreduction of $\mathrm{O}_{2}$ by $\mathrm{Ru}$ complexes. ${ }^{[108]}$ The two compartments were separated by a Nafion membrane. ${ }^{[108]}$ Upon using $\left[\mathrm{Ru}^{\prime \prime}\left\{(\mathrm{MeO})_{2} \mathrm{bpy}\right\}_{3}\right]^{2+} \quad\left[(\mathrm{MeO})_{2} \mathrm{bpy}=4,4^{\prime}\right.$-dimethoxy-2,2'-bipyridine] as the catalyst for the two-electron photoreduction of $\mathrm{O}_{2}$ in the presence of $\mathrm{Sc}\left(\mathrm{NO}_{3}\right)_{3}(100 \mathrm{~mm})$ in an $\mathrm{O}_{2}$-saturated aqueous solution at the carbon mesh cathode and the $\mathrm{BiVO}_{4}$ photoanode, the best performance was obtained in terms of the $\mathrm{H}_{2} \mathrm{O}_{2}$ yield and reaction rate, as shown in Figure 15 . $^{[108]}$

The photocatalytic production of $\mathrm{H}_{2} \mathrm{O}_{2}$ from $\mathrm{H}_{2} \mathrm{O}$ and $\mathrm{O}_{2}$ in a two-compartment cell is shown in Scheme 2. ${ }^{[108]}$ Electron transfer from photogenerated $\left.\left[\mathrm{Ru} \|(\mathrm{MeO})_{2} \mathrm{bpy}\right\}_{3}\right]^{2+*}$ to $\mathrm{O}_{2}$

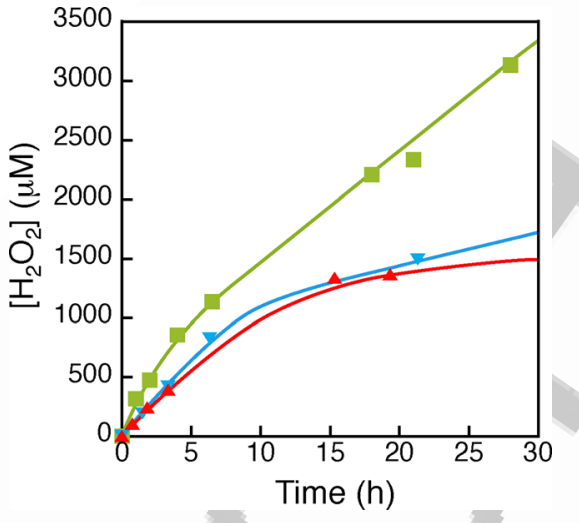

Figure 15. Production of $\mathrm{H}_{2} \mathrm{O}_{2}$ under photoirradiation of a two-compartment cell composed of a semiconductor photocatalyst anode $\left[\mathrm{BiVO}_{4}\right.$ (green and blue lines) or $\mathrm{WO}_{3}$ (red line)] in one cell and a carbon cloth cathode in the presence of $\left[\mathrm{Ru}^{\prime \prime}\left((\mathrm{MeO})_{2} \mathrm{bpy}\right)_{3}\right]^{2+}(160 \mu \mathrm{M}$, black line $)$ or $\left[\mathrm{Ru}^{\prime \prime}\left(\mathrm{Me}_{2} \mathrm{phen}\right)_{3}\right]^{2+}$ (160 $\mu \mathrm{M}$, blue and green lines) in the other cell. Both cells were filled with aqueous solution of $\mathrm{Sc}\left(\mathrm{NO}_{3}\right)_{3}(100 \mathrm{~mm}, 8.0 \mathrm{~mL}$ for each cell). A Xe lamp $(\lambda>420 \mathrm{~nm})$ and a solar simulator were used to irradiate the Ru complex and semiconductor photocatalyst, respectively. ${ }^{[108]}$

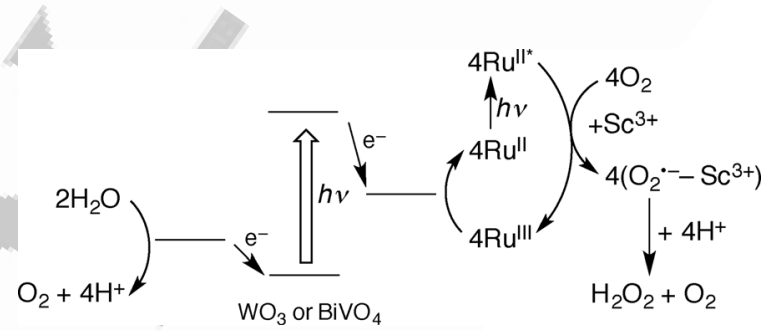

Scheme 2.

occurs to produce $\left[\mathrm{Ru}^{\mathrm{III}}\left\{(\mathrm{MeO})_{2} \mathrm{bpy}\right\}_{3}\right]^{3+}$ and $\mathrm{O}_{2}{ }^{-}$. Strong bind-

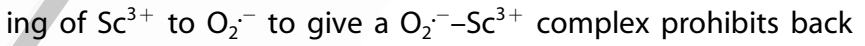
electron transfer from the $\mathrm{O}_{2}{ }^{-}-\mathrm{Sc}^{3+}$ complex to $\left[R u^{\text {III }}\left\{(\mathrm{MeO})_{2} \mathrm{bpy}\right\}_{3}\right]^{3+} \cdot{ }^{[111,112]}$ Disproportionation of the $\mathrm{O}_{2} \cdot--\mathrm{Sc}^{3+}$ complex provides $\mathrm{H}_{2} \mathrm{O}_{2}$ in the presence of $\mathrm{H}^{+}$. On the other hand, $\mathrm{BiVO}_{4}$ catalyzes the photooxidation of water to $\mathrm{O}_{2}$ by using the strong oxidation ability of the photogenerated holes. Reduction of $\left[\mathrm{Ru}^{\mathrm{III}}\left\{(\mathrm{MeO})_{2} \mathrm{bpy}\right\}_{3}\right]^{3+}$ to regenerate $\left[R u^{\prime \prime}\left((\mathrm{MeO})_{2} \mathrm{bpy}\right)_{3}\right]^{2+}$ proceeds by using the photoexcited electrons in the conduction band of $\mathrm{BiVO}_{4}$.

\section{Production and use of Hydrogen Peroxide as a Solar Fuel in Seawater}

Pure water is a limited resource; thus, utilization of earth-abundant seawater instead of pure water is desirable for any practical applications of $\mathrm{H}_{2} \mathrm{O}_{2}$ as a solar fuel. Efficient photocatalytic production of $\mathrm{H}_{2} \mathrm{O}_{2}$ from seawater and $\mathrm{O}_{2}$ in the air was performed in a two-compartment photoelectrochemical cell. The cell used mesoporous $\mathrm{WO}_{3}$ supported on a fluorine-doped tin oxide glass substrate $\left(\mathrm{m}-\mathrm{WO}_{3} / \mathrm{FTO}\right)$ as a photocatalyst for water oxidation and a cobalt chlorin complex supported on a carbon paper [Co" $(\mathrm{Ch}) / \mathrm{CP}]$ for the selective two-electron reduction of $\mathrm{O}_{2}$, as shown in Figure 16. ${ }^{[12]}$ Photoirradiation of $\mathrm{m}-\mathrm{WO}_{3} /$ FTO with a solar simulator (1 sun, AM1.5G) in the anode cell result- 


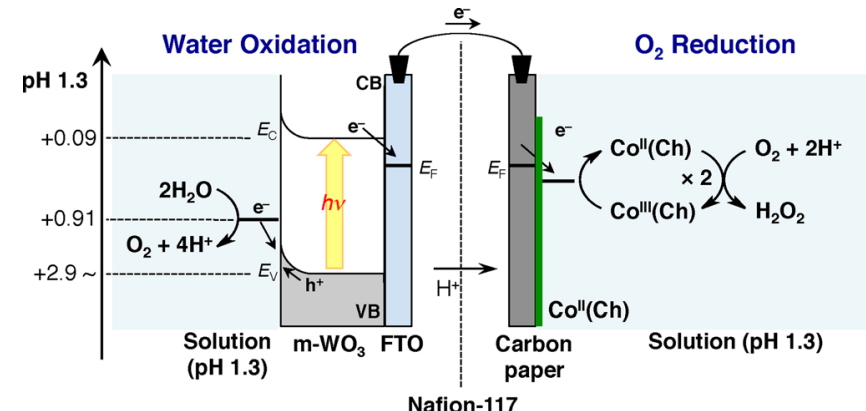

Nafion-117

Figure 16. Photocatalytic production of $\mathrm{H}_{2} \mathrm{O}_{2}$ from water and $\mathrm{O}_{2}$ by using a $\mathrm{m}-\mathrm{WO}_{3} / \mathrm{FTO}$ photoanode and a $\left.\mathrm{Co} / \mathrm{Ch}\right) / \mathrm{CP}$ cathode in water or seawater under simulated 1 sun (AM1.5G) illumination. ${ }^{[112]}$

ed in efficient generation of $\mathrm{H}_{2} \mathrm{O}_{2}$ in the cathode cell of the two-compartment photoelectrochemical configuration without any external bias potential. The time course of the concentration of $\mathrm{H}_{2} \mathrm{O}_{2}$ produced by the photocatalytic reaction is shown in Figure 17. ${ }^{[112]}$ A negligible amount of $\mathrm{H}_{2} \mathrm{O}_{2}$ was formed in the absence of $\mathrm{Co}^{\prime \prime}(\mathrm{Ch})$ on the carbon paper electrode, which suggested that $\mathrm{Co}^{\prime \prime}(\mathrm{Ch})$ efficiently catalyzed the selective twoelectron reduction of $\mathrm{O}_{2}$ to yield $\mathrm{H}_{2} \mathrm{O}_{2}{ }^{[83,112]}$ before charge recombination of the photoexcited electrons in the conduction band and the holes $\square$ ok? $\mathbf{\square}$ generated in the valence band of $\mathrm{WO}_{3}$. After illumination for $24 \mathrm{~h}$, the amount of $\mathrm{H}_{2} \mathrm{O}_{2}$ produced in seawater reached about $48 \mathrm{~mm}$, which was high enough to operate a $\mathrm{H}_{2} \mathrm{O}_{2}$ fuel cell (see below). ${ }^{[112]}$ However, an extreme deceleration in the production of $\mathrm{H}_{2} \mathrm{O}_{2}$ was observed if pure water was used instead of seawater for the photocatalytic $\mathrm{H}_{2} \mathrm{O}_{2}$ production system.

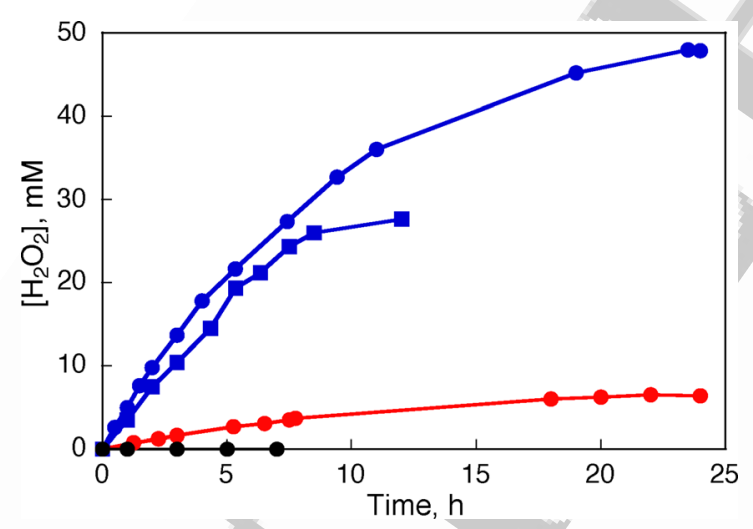

Figure 17. Time course of $\mathrm{H}_{2} \mathrm{O}_{2}$ production with a $\mathrm{m}-\mathrm{WO}_{3} / \mathrm{FTO}$ photoanode and $\mathrm{Co}^{\prime \prime}(\mathrm{Ch}) / \mathrm{CP}$ cathode in $\mathrm{pH} 1.3$ water $(\bullet)$, in $\mathrm{pH} 1.3$ seawater $(\bullet)$, and in an $\mathrm{NaCl}$ aqueous solution ( $\mathrm{pH}$ 1.3) (⿴) under simulated 1 sun (AM1.5G) illumination. Time course of $\mathrm{H}_{2} \mathrm{O}_{2}$ production in the absence of $\mathrm{Co}$ " $(\mathrm{Ch})$ from carbon paper under simulated 1 sun (AM1.5G) illumination in $\mathrm{pH} 1.3$ water is also shown $(\bullet)^{[112]}$

An enhancement in the photocatalytic activity was observed in an $\mathrm{NaCl}$ solution for the reaction system in which seawater was used, and the concentration of $\mathrm{NaCl}$ was the same as that in seawater $\mathbf{\square}$ ok? $\mathbf{\square}$. The enhanced photocatalytic activity for water oxidation in the presence of $\mathrm{NaCl}$ was elucidated by the following $\mathrm{Cl}^{-}$-mediated mechanism. ${ }^{[113-117]}$ Upon photoexcitation of $\mathrm{WO}_{3}, \mathrm{Cl}^{-}$oxidation by photogenerated holes resulted in the formation of chlorine $\left(\mathrm{Cl}_{2}\right)$, which occurred prior to the oxidation of water [Eq. (4)]. ${ }^{[14]} \mathrm{Cl}_{2}$ thus formed reacted with water to form $\mathrm{HClO}$ depending on the $\mathrm{pH}$ of the reaction solution [Eq. (5)]. ${ }^{[115]}$ Decomposition of $\mathrm{HClO}$ provided $\mathrm{O}_{2}$ and $\mathrm{Cl}^{-}$ under photoirradiation [Eq. (6)]. ${ }^{[115]}$ Thus, the water oxidation efficiently proceeded by using $\mathrm{Cl}^{-}$as a mediator [Eq. (7)]. The formation of $\mathrm{HClO} / \mathrm{Cl}_{2}$ was confirmed during the photocatalytic water oxidation in the presence of $\mathrm{Cl}^{-}{ }^{[112]}$

$$
\begin{aligned}
& 2 \mathrm{Cl}^{-}+2 \mathrm{~h}^{+} \stackrel{h v}{\longrightarrow} \mathrm{Cl}_{2} \\
& \mathrm{Cl}_{2}+\mathrm{H}_{2} \mathrm{O} \rightleftharpoons \mathrm{HClO}+\mathrm{H}^{+}+\mathrm{Cl}^{-} \\
& 2 \mathrm{HClO} \stackrel{h v}{\longrightarrow} \mathrm{O}_{2}+2 \mathrm{H}^{+}+2 \mathrm{Cl}^{-} \\
& 2 \mathrm{H}_{2} \mathrm{O}+4 \mathrm{~h}^{+} \stackrel{h v}{\longrightarrow} \mathrm{O}_{2}+4 \mathrm{H}^{+}
\end{aligned}
$$

The amount of $\mathrm{O}_{2}$ evolved after photoirradiation for $1 \mathrm{~h}$ $(12.7 \mu \mathrm{mol})$ in the anode cell containing seawater was more than three times larger than that in pure water $(3.7 \mu \mathrm{mol})$. Thus, the enhancement in the photocatalytic production of $\mathrm{H}_{2} \mathrm{O}_{2}$ in seawater (Figure 17) resulted from the $\mathrm{Cl}^{-}$-catalyzed photooxidation of water. ${ }^{[112]}$

A high solar energy conversion efficiency of $0.55 \%$ was achieved in the photocatalytic production of $\mathrm{H}_{2} \mathrm{O}_{2}$ in seawater under photoirradiation with a solar simulator (1 sun, 1.5AM). ${ }^{[12]}$ A higher solar energy conversion efficiency of $0.94 \%$ was achieved if the illumination intensity was reduced to 0.1 sun. This efficiency exceeds that of swichgrass $(0.2 \%)$, which is regarded as a promising biomass crop for the production of biofuel, ${ }^{[117]}$ and also exceeds the value for photocatalytic $\mathrm{H}_{2} \mathrm{O}_{2}$ production in a one-compartment cell $(0.25 \%) .{ }^{[90]}$

The chemical energy of $\mathrm{H}_{2} \mathrm{O}_{2}$ produced by the photocatalytic oxidation of seawater by the $\mathrm{O}_{2}$ in the air was converted into electricity by using a one-compartment $\mathrm{H}_{2} \mathrm{O}_{2}$ fuel cell by employing a $\mathrm{Fe}_{3}{ }_{3}\left[\mathrm{Co}^{\text {"II }}(\mathrm{CN})_{6}\right]_{2}$-modified carbon cloth and a nickel mesh as the cathode and anode, respectively. ${ }^{[12]}$ The reaction solution (seawater, pH 1.3) containing about $48 \mathrm{~mm}$ of $\mathrm{H}_{2} \mathrm{O}_{2}$ produced by the photocatalytic reaction was transferred into the $\mathrm{H}_{2} \mathrm{O}_{2}$ fuel cell. The cell exhibited an OCP of $0.78 \mathrm{~V}$ and a maximum power density of $1.6 \mathrm{~mW} \mathrm{~cm}^{-2}$ (Figure 18). ${ }^{[12]}$ The energy conversion efficiency of the $\mathrm{H}_{2} \mathrm{O}_{2}$ fuel cell was determined to be around $50 \%$ by measuring the output energy as electrical energy versus consumed chemical energy of $\mathrm{H}_{2} \mathrm{O}_{2}$; this value is comparable to the efficiency of a $\mathrm{H}_{2}$ fuel cell. ${ }^{[112]}$

\section{Conclusions}

The most serious problem accompanied with the use of $\mathrm{H}_{2}$ as an energy carrier has been solved by using a high-pressure tank with an extremely high strength, which was developed only recently. However, the tank cannot be incorporated into personal-based small electric devices such as cell phones. For this purpose, liquid or solid energy carriers storable in lightweight containers are necessary. These days, the capacity and 


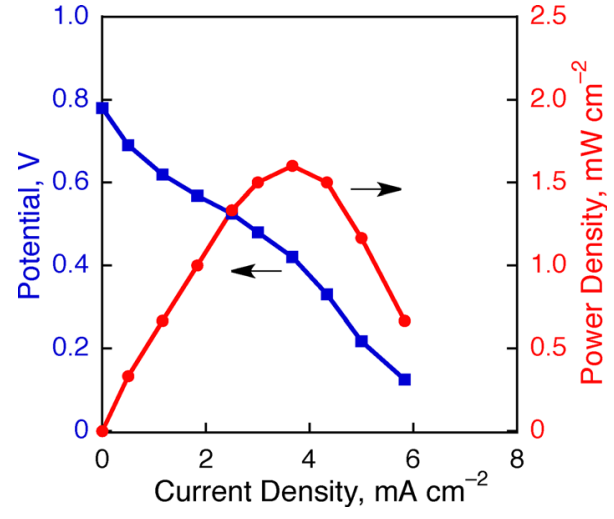

Figure 18. $I-V(\square)$ and $I-P(\bullet)$ curves of the one-compartment $\mathrm{H}_{2} \mathrm{O}_{2}$ fuel cell with a $\mathrm{Ni}$ mesh anode and $\mathrm{Fe}_{3}{ }_{3}\left[\mathrm{Co}{ }^{\prime \prime \prime}(\mathrm{CN})_{6}\right]_{2} /$ carbon cloth cathode in the reaction solution containing $\mathrm{H}_{2} \mathrm{O}_{2}(47.9 \mathrm{~mm})$ produced by photocatalytic reaction in seawater as shown in Figure $17(\bullet) .{ }^{[112]}$

durability of lithium-ion batteries have been much improved; however, high costs and limited resources remain critical issues. $\mathrm{H}_{2} \mathrm{O}_{2}$ can be an alternative sustainable and green fuel for personal-based electric items, because abundant oxygen, water, and sunlight are resources, and power generation is possible with a fuel cell with a simple one-compartment structure. $\square$ paragraph ok?

As described above, the proof of concept has been demonstrated for the production of $\mathrm{H}_{2} \mathrm{O}_{2}$ from sweater and the $\mathrm{O}_{2}$ in the air by using solar energy and its direct use on demand as a fuel in one-compartment $\mathrm{H}_{2} \mathrm{O}_{2}$ fuel cells. There are still many things left to improve the performance of one-compartment $\mathrm{H}_{2} \mathrm{O}_{2}$ fuel cells, including the development of better cathode and anode materials. One-compartment cells without any membranes and the use of seawater containing $\mathrm{H}_{2} \mathrm{O}_{2}$ are more advantageous than the production of gaseous $\mathrm{H}_{2}$ and its use in $\mathrm{H}_{2}$ fuel cells, because seawater is the most earth-abundant resource. The production of fuels by utilizing solar energy and the generation of electricity with the fuels in seawater are beneficial for practical applications. Further improvement in the photocatalytic activity for the production of $\mathrm{H}_{2} \mathrm{O}_{2}$ from seawater and $\mathrm{O}_{2}$ together with more efficient one-compartment $\mathrm{H}_{2} \mathrm{O}_{2}$ fuel cells without membranes for use in personal-based sustainable energy-conversion systems are targets for the future. $\square$ ok?

\section{Acknowledgements}

The authors gratefully acknowledge the contributions of their collaborators and co-workers mentioned in the cited references and financial support from the ALCA and SENTAN projects from the Japan Science and Technology Agency (JST) and Japan Society for the Promotion of Science (JSPS) KAKENHI (Grant numbers $16 \mathrm{H} 02268$ to S.F. and $15 \mathrm{~K} 14223$ to Y.Y.) from the Ministry of Education, Culture, Sports, Science and Technology (MEXT), Japan.

\section{ok?}

Keywords: energy conversion - fuel cells - hydrogen peroxides · photocatalysis · solar fuels

[1] T. A. Faunce, W. Lubitz, A. W. Rutherford, D. MacFarlane, G. F. Moore, P. Yang, D. G. Nocera, T. A. Moore, D. H. Gregory, S. Fukuzumi, K. B. Yoon, F. A. Armstrong, M. R. Wasielewski, S. Styring, Energy Environ. Sci. 2013, 6, 695-698.

[2] N. S. Lewis, D. G. Nocera, Proc. Natl. Acad. Sci. USA 2006, 103, 1572915735.

[3] D. Kim, K. K. Sakimoto, D. Hong, P. Yang, Angew. Chem. Int. Ed. 2015, 54, 3259-3266; Angew. Chem. 2015, 127, 3309-3316.

[4] E. W. McFarland, Energy Environ. Sci. 2014, 7, 846-854.

[5] G. Gahleitner, Int. J. Hydrogen Energy 2013, 38, 2039-2061.

[6] S. Fukuzumi, Y. Yamada, T. Suenobu, K. Ohkubo, H. Kotani, Energy Environ. Sci. 2011, 4, 2754-2766.

[7] M. Momirlan, T. N. Veziroglub, Int. J. Hydrogen Energy 2005, 30, 795 802.

[8] S. Fukuzumi, Eur. J. Inorg. Chem. 2008, 1351-1362.

[9] R. S. Disselkamp, Energy Fuels 2008, 22, 2771- 2774.

[10] R. S. Disselkamp, Int. J. Hydrogen Energy 2010, 35, 1049-1053.

[11] R. S. Disselkamp, Appl. Energy 2011, 88, 4214-4217.

[12] L. An, T. Zhao, X. Yan, X. Zhou, P. Tan, Sci. Bull. 2015, 60, 55-64.

[13] S. Fukuzumi, Y. Yamada, K. D. Karlin, Electrochim. Acta 2012, 82, 493 511.

[14] S. Fukuzumi, Y. Yamada, Aust. J. Chem. 2014, 67, 354-364.

[15] S. Fukuzumi, Biochim. Biophys. Acta Bioenerg. 2016, 1857, 604-611.

[16] W. Scholz, F. Galván, F. F. de la Rosa, Solar Energy Mater. Solar Cells $1995,39,61-69$.

[17] F. F. de la Rosa, O. Montes, F. Galván, Biotechnol. Bioeng. 2001, 74, 539543.

[18] M. Mubarakshina, S. Khorobrykh, B. Ivanov, Biochim. Biophys. Acta Bioenerg. 2006, 1757, 1496-1503.

[19] R. Simard, Eng. J. 1948, 31, 219-225. @ please check this reference

[20] E. Burgess, J. Am. Rocket Soc. 1946, 00, 18-19. qvolume ok?

[21] S. Bonifacio, G. Festa, A. R. Sorge, J. Propul. Power 2013, 29, 1130 1137.

[22] B. Li, M. Jonsson, M. Algotsson, J. Bood, Z. S. Li, O. Johansson, M. Aldén, M. Tunér, B. Johansson, Proc. Combust. Inst. 2013, 34, 3573 3581.

[23] N. Kurimoto, B. Brumfield, X. Yang, T. Wada, P. Diévart, G. Wysocki, Y. Ju, Proc. Combust. Inst. 2015, 35, 457-464.

[24] O. V. Romantsova, V. B. Ulybin, Acta Astronaut. 2015, 109, 231 - 234.

[25] Z. Zhang, A. Zhao, F. Wang, J. Rena, X. Qu, Chem. Commun. 2016, 52, $5550-5553$.

[26] W. Z. Teo, H. Wang, M. Pumera, Chem. Commun. 2016, 52, 4333-4336.

[27] A. A. Solovev, E. J. Smith, C. C. Bof'Bufon, S. Sanchez, O. G. Schmidt, Angew. Chem. Int. Ed. 2011, 50, 10875-10878; Angew. Chem. 2011, 123, 11067-11070.

[28] H. Wang, G. Zhao, M. Pumera, J. Am. Chem. Soc. 2014, 136, 2719 2722.

[29] A. Martín, B. Jurado-Sánchez, A. Escarpa, J. Wang, Small 2015, 11, 499 506. Dlease check this reference

[30] H. Wang, Z. Sofer, A. Y. S. Eng, M. Pumera, Chem. Eur. J. 2014, 20, $14946-14950$.

[31] E. Santacesaria, M. D. Serio, R. Velotti, U. Leone, Ind. Eng. Chem. Res. 1994, 33, 277-284.

[32] J. M. Campos-Martin, G. Blanco-Brieva, J. L. G. Fierro, Angew. Chem. Int. Ed. 2006, 45, 6962-6984; Angew. Chem. 2006, 118, 7116-7139.

[33] M. M. Borisova, M. A. Kozuleva, N. N. Rudenko, I. A. Naydov, I. B. Klenina, B. N. Ivanov, Biochim. Biophys. Acta Bioenerg. 2012, 1817, 13141321.

[34] M. R. Badger, S. von Caemmerer, S. Ruuska, H. Nakano, Philos. Trans. R. Soc. London Ser. B 2000, 355, 1433-1446.

[35] I. V. Kuvykin, A. V. Vershubskii, V. V. Ptushenko, A. N. Tikhonov, Biochem. Mosc. 2008, 73, 1063-1075.

[36] D. D. Wagman, J. Phys. Chem. Ref. Data 1982, 11, Supplement No. 2.

[37] M. Kutz, Mechanical Engineers' Handbook 4: Energy and Power, Wiley, New York, 2015. 
[38] S. Yamazaki, Z. Siroma, H. Senoh, T. Ioroi, N. Fujiwara, K. Yasuda, J. Power Sources 2008, 178, 20-25.

[39] Y. Yamada, Y. Fukunishi, S. Yamazaki, S. Fukuzumi, Chem. Commun. 2010, 46, 7334-7336.

[40] Y. Yamada, S. Yoshida, T. Honda, S. Fukuzumi, Energy Environ. Sci. 2011, 4, $2822-2825$.

[41] S. A. M. Shaegh, N. T. Nguyen, S. M. M. Ehteshami, S. H. A. Chan, Energy Environ. Sci. 2012, 5, 8225-8228.

[42] Y. Yamada, M. Yoneda, S. Fukuzumi, Chem. Eur. J. 2013, 19, 11733 11741.

[43] Y. Yamada, M. Yoneda, S. Fukuzumi, Energy Environ. Sci. 2015, 8, 1698 1701.

[44] Y. Yamada, M. Yoneda, S. Fukuzumi, Inorg. Chem. 2014, 53, 1272-1274.

[45] A. Pariyar, G. Vijaykumar, M. Bhunia, S. K. Dey, S. K. Singh, S. Kurungot, S. K. Mandal, J. Am. Chem. Soc. 2015, 137, 5955-5960.

[46] A. E. Sanlı, A. Aytac, Int. J. Hydrogen Energy 2011, 36, 869-875. aplease check this reference

[47] F. Yang, K. Cheng, X. Liu, S. Chang, J. Yin, C. Du, L. Du, G. Wang, D. Cao, J. Power Sources 2012, 217, 569-573.

[48] F. Yang, K. Cheng, T. Wu, Y. Zhang, J. Yin, G. Wang, D. Cao, Electrochim. Acta 2013, 99, 54-61.

[49] A. E. Sanli, Int. J. Energy Res. 2013, 37, 1488-1497.

[50] F. Yang, K. Cheng, T. Wu, Y. Zhang, J. Yin, G. Wang, D. Cao, RSC Adv. 2013, 3, 5483-5490.

[51] F. Yang, K. Cheng, X. Xiao, J. Yin, G. Wang, D. Cao, J. Power Sources 2014, 245, 89-94.

[52] K. Ye, F. Guo, Y. Gao, D. Zhang, K. Cheng, W. Zhang, G. Wang, D. Cao, J. Power Sources 2015, 300, 147-156.

[53] F. Yang, K. Cheng, X. Liu, S. Chang, J. Yin, C. Du, L. Du, G. Wang, D. Cao, J. Power Sources 2012, 217, $562-568$

[54] D. Duan, X. You, J. Liang, S. Liu, Y. Wang, Electrochim. Acta 2015, 176, $1126-1135$.

[55] L. Yi, W. Wei, C. Zhao, L. Tian, J. Liu, X. Wang, J. Power Sources 2015 $285,325-333$

[56] L. Yi, Y. Song, X. Liu, X. Wang, G. Zou, P. He, W. Yi, Int. J. Hydrogen Energy 2011, 36, 15775-15782.

[57] D. Cao, Y. Gao, G. Wang, R. Miao, Y. Liu, Int. J. Hydrogen Energy 2010, $35,807-813$

[58] H. Wu, C. Wang, Z. Liu, Z. Mao, Int. J. Hydrogen Energy 2010, 35, 2648 2651. — please check this reference

[59] J. P. Charles, R. B. Russell, K. K. Yong, R. S. Christian, J. Electrochem. Soc. 2008, 155, B558-B562.

[60] K. Naga Mahesh, R. Balaji, K. S. Dhathathreyan, lonics 2015, 21, 2603 2607.

[61] K. Liu, C.-A. Wang, J.-T. Ma, RSC Adv. 2014, 4, 18894-18898.

[62] L. An, T. S. Zhao, X. L. Zhou, X. H. Yan, C. Y. Jung, J. Power Sources 2015, 275, 831-834

[63] W. Yang, S. Yang, W. Sun, G. Sun, Q. Xin, Electrochim. Acta 2006, 52, 914.

[64] T. Bewer, T. Beckmann, H. Dohle, J. Mergel, D. Stolten, J. Power Sources 2004, 125, 1 -9.

[65] X. H. Yan, T. S. Zhao, L. An, G. Zhao, L. Shi, Int. J. Hydrogen Energy 2016 41, 5130-5140.

[66] D. N. Prater, J. J. Rusek, Appl. Energy 2003, 74, 135-140.

[67] L. An, T. S. Zhao, X. L. Zhou, L. Wei, X. H. Yan, RSC Adv. 2014, 4, 65031 65034.

[68] S. P. S. Badwal, S. Giddey, A. Kulkarni, J. Goel, S. Basu, Appl. Energy 2015, 145, 80-103.

[69] S. J. Lao, H. Y. Qin, L. Q. Ye, B. H. Liu, Z. P. Li, J. Power Sources 2010, 195 $4135-4138$.

[70] A. E. Sanlı, M. D. Mat, Int. J. Hydrogen Energy 2015, 40, 6440-6448. please check this reference

[71] A. Sanlı, O. Yilmaz, A. Aytac, Int. J. Energy Res. 2013, 37, 1205-1212. please check this reference $\mathbf{\square}$

[72] P. Vidossich, M. Alfonso-Prieto, X. Carpena, I. Fita, P. C. Loewen, C. Rovira, Arch. Biochem. Biophys. 2010, 500, 37-44.

[73] R. Palangsuntikul, M. Somasundrum, W. Surareungchai, Electrochim. Acta 2010, 56, 470-475.

[74] T. Ruzgas, L. Gorton, J. Emnéus, G. Marko-Varga, J. Electroanal. Chem. $1995,391,41-49$.
[75] D. Sović, A. Gajović, D. Iveković, Electrochim. Acta 2011, 56, 9953 9960.

[76] S. Fukuzumi, K. Ohkubo, Chem. Eur. J. 2000, 6, 4532-4535.

[77] S. Fukuzumi, K. Ohkubo, J. Am. Chem. Soc. 2002, 124, 10270-10271.

[78] S. Fukuzumi, Prog. Inorg. Chem. 2009, 56, 49-153.

[79] S. Kakuda, C. Rolle, K. Ohkubo, K. D. Karlin, S. Fukuzumi, J. Am. Chem. Soc. 2015, 137, 3330-3337.

[80] S. Fukuzumi, S. Mochizuki, T. Tanaka, Inorg. Chem. 1989, 28, $2459-$ 2465.

[81] I. Hatay, B. Su, F. Li, M. A. Mendez, T. Khoury, C. P. Gros, J.-M. Barbe, M. Ersoz, Z. Samec, H. H. Girault, J. Am. Chem. Soc. 2009, 131, $13453-$ 13459.

[82] K. Mase, K. Ohkubo, S. Fukuzumi, Inorg. Chem. 2015, 54, 1808-1815

[83] K. Mase, K. Ohkubo, S. Fukuzumi, J. Am. Chem. Soc. 2013, 135, 2800 2808.

[84] T. Honda, T. Kojima, S. Fukuzumi, J. Am. Chem. Soc. 2012, 134, $4196-$ 4206.

[85] B. Su, I. Hatay, A. Trojanek, Z. Samec, T. Khoury, C. P. Gros, J.-M. Barbe, A. Daina, P.-A. Carrupt, H. H. Girault, J. Am. Chem. Soc. 2010, 132, $2655-2662$.

[86] K. M. Kadish, J. Shen, L. Fremond, P. Chen, M. El Ojaimi, M. Chkounda, C. P. Gros, J.-M. Barbe, K. Ohkubo, S. Fukuzumi, R. Guilard, Inorg. Chem 2008, 47, 6726-6737.

[87] S. Fukuzumi, K. Okamoto, C. P. Gros, R. Guilard, J. Am. Chem. Soc. 2004 126, $10441-10449$

[88] J. Qu, Y. Shen, X. Qu, S. Dong, Electroanalysis 2004, 16, 1444-1450.

[89] M. S. El-Deab, S. H. Othman, T. Okajima, T. Ohsaka, J. Appl. Electrochem. 2008, 38, 1445-1451.

[90] S. Kato, J. Jung, T. Suenobu, S. Fukuzumi, Energy Environ. Sci. 2013, 6 $3756-3764$

[91] A. Das, V. Joshi, D. Kotkar, V. S. Pathak, V. Swayambunathan, P. V. Kamat, P. K. Ghosh, J. Phys. Chem. A 2001, 105, 6945-6954.

[92] X. Wu, F. Li, B. Zhang, L. Sun, J. Photochem. Photobiol. C 2015, 25, 71 89.

[93] S. Fukuzumi, J. Jung, Y. Yamada, T. Kojima, W. Nam, Chem. Asian J. 2016, 11, 1138

[94] M. Okamura, S. Masaoka, Chem. Asian J. 2015, 10, 306-315.

[95] S. Fukuzumi, D. Hong, Eur. J. Inorg. Chem. 2014, 645-659.

[96] Q. Yin, J. M. Tan, C. Besson, Y. V. Geletii, D. G. Musaev, A. E. Kuznetsov Z. Luo, K. I. Hardcastle, C. L. Hill, Science 2010, 328, 342-345.

[97] H. Lv, J. Song, Y. V. Geletii, J. W. Vickers, J. M. Sumliner, D. G. Musaev, P. Kögerler, P. F. Zhuk, J. Bacsa, G. Zhu, C. L. Hill, J. Am. Chem. Soc. 2014, 136, 9268-9271.

[98] S. Fukuzumi, D. Hong, Y. Yamada, J. Phys. Chem. Lett. 2013, 4, $3458-$ 3467.

[99] A. R. Parent, K. Sakai, ChemSusChem 2014, 7, 2070-2080.

[100] S. Berardi, S. Drouet, L. Francas, C. Gimbert-Surinach, M. Guttentag, C. Richmond, T. Stoll, A. Llobet, Chem. Soc. Rev. 2014, 43, 7501-7519.

[101] J. D. Blakemore, R. H. Crabtree, G. W. Brudvig, Chem. Rev. 2015, 115, $12974-13005$

[102] D. Hong, M. Murakami, Y. Yamada, S. Fukuzumi, Energy Environ. Sci. 2012, 5, 5708-5716.

[103] Y. Yamada, K. Oyama, R. Gates, S. Fukuzumi, Angew. Chem. Int. Ed. 2015, 54, 5613-5617; Angew. Chem. 2015, 127, 5705-5709.

[104] Y. Shiraishi, S. Kanazawa, Y. Kofuji, H. Sakamoto, S. Ichikawa, S. Tanaka, T. Hirai, Angew. Chem. Int. Ed. 2014, 53, 13454-13459; Angew. Chem. 2014, 126, 13672-13677.

[105] D. Hong, Y. Yamada, T. Nagatomi, Y. Takai, S. Fukuzumi, J. Am. Chem Soc. 2012, 134, $19572-19575$.

[106] Y. Isaka, S. Kato, D. Hong, T. Suenobu, Y. Yamada, S. Fukuzumi, J. Mater. Chem. A 2015, 3, 12404-12412.

[107] Y. Isaka, Y. Yamada, T. Suenobu, S. Fukuzumi, Catal. Sci. Technol. 2016 $6,681-684$

[108] Y. Isaka, Y. Yamada, K. Ohkubo, T. Suenobu, S. Fukuzumi, RSC Adv. 2016, 6, $42041-42044$

[109] P. Xu, J. Feng, T. Fang, X. Zhao, Z. Li, Z. Zou, RSC Adv. 2016, 6, $9905-$ 9910.

[110] Y. Park, K. J. McDonald, K.-S. Choi, Chem. Soc. Rev. 2013, 42, 2321 2337.

[111] S. Fukuzumi, M. Patz, T. Suenobu, Y. Kuwahara, S. Itoh, J. Am. Chem. Soc. 1999, 121, 1605-1606. 
[112] K. Mase, M. Yoneda, Y. Yamada, S. Fukuzumi, Nat. Commun. 2016, 7 11470.

[113] Z. Chen, J. J. Concepcion, N. Song, T. J. Meyer, Chem. Commun. 2014 $50,8053-8056$.

[114] S. Nakagawara, T. Goto, M. Nara, Y. Ozawa, K. Hotta, Y. Arata, Anal. Sci. 1998, 14, $691-698$.

[115] L. Huang, R. Li, R. Chong, G. Liu, J. Han, C. Li, Catal. Sci. Technol. 2014 4, 2913-2918.
[116] Y. Miseki, K. Sayama, RSC Adv. 2014, 4, 8308-8316. [117] A. Melis, Plant Sci. 2009, 177, 272-280.

Manuscript received: June 14, 2016

Accepted Article published: September 23, 2016

Final Article published: $\mathbf{\square} \mathbf{\square}, 2016$ 
So much to sea: Hydrogen peroxide can be produced from seawater and dioxygen by using solar energy. This article provides a focused review of recent developments and future perspectives of $\mathrm{H}_{2} \mathrm{O}_{2}$ fuel cells without membranes, combined with $\mathrm{H}_{2} \mathrm{O}_{2}$ production from seawater and dioxygen in the air by utilizing solar energy.

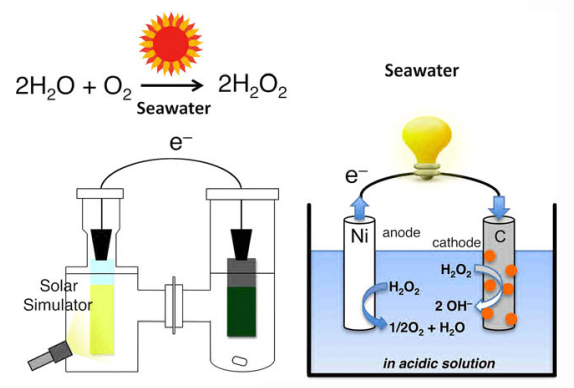

S. Fukuzumi, * Y. Yamada*

$\mathbf{\square}-\mathbf{\square}$

Hydrogen Peroxide used as a Solar Fuel in One-Compartment Fuel Cells

Review on hydrogen peroxide as a \#SolarFuel in one-compartment \#FuelCells @EwhaWomansUniv SPACE

RESERVED FOR IMAGE AND LINK

Share your work on social media! ChemElectroChem has added Twitter as a means to promote your article. Twitter is an online microblogging service that enables its users to send and read text-based messages of up to 140 characters, known as "tweets". Please check the pre-written tweet in the galley proofs for accuracy. Should you or your institute have a Twitter account, please let us know the appropriate username (i.e., @accountname), and we will do our best to include this information in the tweet. This tweet will be posted to the journal's Twitter account @ChemElectroChem (follow us!) upon online publication of your article, and we recommended you to repost ("retweet") it to alert other researchers about your publication.

Please check that the ORCID identifiers listed below are correct. We encourage all authors to provide an ORCID identifier for each coauthor. ORCID is a registry that provides researchers with a unique digital identifier. Some funding agencies recommend or even require the inclusion of ORCID IDs in all published articles, and authors should consult their funding agency guidelines for details. Registration is easy and free; for further information, see http://orcid.org/.

Prof. Dr. Shunichi Fukuzumi

Prof. Dr. Yusuke Yamada 